\title{
Olefins from conventional and heavy feedstocks: Energy use in steam cracking and alternative processes
}

\author{
Tao Ren*, Martin Patel, Kornelis Blok \\ Department of Science, Technology and Society, Faculty of Chemistry, Utrecht University, \\ Heidelberglaan 2, 3584 CS Utrecht, The Netherlands
}

Received 1 June 2004

\begin{abstract}
Steam cracking for the production of light olefins, such as ethylene and propylene, is the single most energyconsuming process in the chemical industry. This paper reviews conventional steam cracking and innovative olefin technologies in terms of energy efficiency. It is found that the pyrolysis section of a naphtha steam cracker alone consumes approximately $65 \%$ of the total process energy and approximately $75 \%$ of the total exergy loss. A family portrait of olefin technologies by feedstocks is drawn to search for alternatives. An overview of state-of-the-art naphtha cracking technologies shows that approximately $20 \%$ savings on the current average process energy use are possible. Advanced naphtha cracking technologies in the pyrolysis section, such as advanced coil and furnace materials, could together lead to up to approximately $20 \%$ savings on the process energy use by state-of-the-art technologies. Improvements in the compression and separation sections could together lead to up to approximately $15 \%$ savings. Alternative processes, i.e. catalytic olefin technologies, can save up to approximately $20 \%$.

(C) 2005 Elsevier Ltd. All rights reserved.
\end{abstract}

\section{Introduction}

Steam cracking ${ }^{1}$ is the most energy-consuming process in the chemical industry and globally uses approximately $8 \%^{2}$ of the sector's total primary energy use, excluding energy content of final

\footnotetext{
* Corresponding author. Tel.: +31 30253 7687; fax: +31 302537601.

E-mail address: t.ren@chem.uu.nl (T. Ren).

${ }^{1}$ Steam cracking includes all production processes in a steam cracker, i.e. from pyrolysis to separation. See process description later.

${ }^{2}$ Our estimate is based on the energy data given in $[1,2]$.
} 


\author{
Nomenclature \\ BTX benzene, toluene and xylene \\ ${ }^{\circ} \mathrm{C}$ centigrade \\ $\mathrm{C}_{2} \quad$ ethylene and ethane \\ $\mathrm{C}_{3} \quad$ propylene and propane \\ $\mathrm{C}_{4} \quad$ butadiene and butylenes \\ CPP catalytic pyrolysis process \\ EJ exa Joules $\left(10^{18}\right)$ \\ FCC fluidized catalytic cracking \\ GJ giga Joules $\left(10^{9}\right)$ \\ HIDiC heat integrated distillation column \\ LHV lower heating value \\ $\mathrm{mm}$ millimeter \\ MVR mechanical vapor recompression \\ $\mathrm{P} / \mathrm{E}$ propylene/ethylene \\ SEC specific energy consumption \\ $\mathrm{T}$ temperature \\ $\mathrm{t} \quad$ tonne or metric ton \\ TLE transfer line exchangers \\ VSA vacuum swing adsorption \\ Wt weight or mass basis
}

products excluded. In this process, hydrocarbon feedstocks, such as naphtha, ethane, etc. are converted to light olefins, such as ethylene and propylene, and other products. Light olefins are mostly used to produce plastics, fibers and other chemicals. The steam cracking process currently accounts for approximately 180-200 million tons of $\mathrm{CO}_{2}$ emissions worldwide ${ }^{3}$ (see Table 1). Reduction of the emissions can help to meet the emission targets set by the Kyoto Protocol [4]. Energy cost counts for approximately $70 \%$ of production costs in typical ethane- or naphtha-based olefin plants. From both environmental and economic perspectives, it is therefore of interest to study energy losses in the existing processes as well as energy-saving potentials offered by recent improvements and alternative processes. Also, R\&D priority setting and innovation policy studies could benefit from such characterization.

Many technical papers have described alternative olefin processes with an emphasis on technical details of catalysis and engineering [5]. Some techno-economic studies for various ethylene processes were done in the 1980s [6]. A number of new olefin production technologies for short-term development were also reviewed [7]. An updated, thorough comparison of alternative olefin technologies and steam cracking that takes into account energy allocation to by-products and all feedstock production

\footnotetext{
${ }^{3}$ Our estimate is based on energy data in $[1,2]$ and production data in [3].
} 
Table 1

Estimated global energy use and $\mathrm{CO}_{2}$ emission by current olefin production (in million tons)

\begin{tabular}{|c|c|c|c|}
\hline & World & US & $\begin{array}{l}\text { Europe (enlarged EU and } \\
\text { former Soviet Union States) }\end{array}$ \\
\hline Total feedstocks ${ }^{\mathrm{a}}$ & 300 & 85 & 90 \\
\hline $\begin{array}{l}\text { Breakdown of } \\
\text { feedstocks (wt } \%)\end{array}$ & $\begin{array}{l}\text { Naphtha } 55, \\
\text { ethane } 30, \\
L^{b} G^{b} 10, \\
\text { gas oil } 5\end{array}$ & $\begin{array}{l}\text { Ethane } 55, \\
\text { naphtha } 23, \\
\text { propane } 15, \\
\text { gas oil } 5\end{array}$ & $\begin{array}{l}\text { Naphtha } 75, \\
\text { LPG } 10, \\
\text { gas oil } 9, \\
\text { ethane } 5\end{array}$ \\
\hline Ethylene capacity & $110-113$ & $28-30$ & $\begin{array}{l}30-32 \\
\text { (75\% in Western } \\
\text { Europe) }\end{array}$ \\
\hline Propylene capacity & $53-55$ & $16-17$ & $17-18$ \\
\hline $\begin{array}{l}\text { Total energy use } \\
\text { (fuel combustion } \\
\text { and utilities } \\
\text { included) (EJ) }\end{array}$ & $2-3$ & $0.5-0.6$ & $0.7-0.8$ \\
\hline $\begin{array}{l}\text { Total } \mathrm{CO}_{2} \text { emissions } \\
\text { (fuel combustion, } \\
\text { decoking and utilities } \\
\text { included) }\end{array}$ & $180-200$ & $43-45$ & $53-55$ \\
\hline
\end{tabular}

We estimated energy use on the basis of current production level. The annual growth rate of olefin production for 2003-2004 is assumed at $3.5 \%[10]$.

a Feedstock, ethylene and propylene production data are based on [3,64]; US figures come from [19].

b LPG is a mixture of ethane, ethylene, propane, propylene, butane and butylenes.

${ }^{c}$ Since the world production between 1994 and 2004 went up from 50 to over 110 million tons of ethylene per year, we estimated that global energy used in olefin production has more than doubled from 1 EJ in 1994 [65]. US. Department of Energy put the global process energy used in ethylene production as $2.6 \mathrm{EJ}$ when the global ethylene production is 93 million tons in 2000 [66].

${ }^{\mathrm{d}} \mathrm{CO}_{2}$ emission and process energy use are based on [9,21]. Decoking is based on [27]. US figures are lower than those of Europe due the fact that heavy feedstock uses more energy use in total.

is still missing. Therefore, our research question is: what are the possible technological developments in steam cracking and in alternative processes for the coming decade and how does their potential energy efficiency compare?

For confidentiality reasons, only a few articles in the open literature have presented quantitative energy analysis of steam cracking. Sources used in this paper can be divided into the following categories: government reports (e.g. by the US Department of Energy), journals (e.g. Oil \& Gas journal) and conference proceedings (e.g. meetings of American Institute of Chemical Engineers). Personal communications were also helpful.

Our research approach follows two stages. First, the existing processes and energy use are studied. Then, an inventory of new technologies is made and technologies are characterized in terms of potential energy-efficiency improvement. The scope of technologies in this paper is limited to those that produce olefins from conventional feedstock and heavy feedstock only. Also, due to its large share as a feedstock (Table 1), naphtha cracking is the main subject and ethane cracking is discussed 
less. Technologies involving other feedstocks, i.e. natural gas, biomass, coal, organic waste and $\mathrm{CO}_{2}$ will not be discussed. ${ }^{4}$

This paper first reviews background factors in Section 2. Section 3 gives a process description for naphtha cracking. Definitions are given in Section 4. Section 5 presents the results of energy analysis. In Section 6, state-of-the-art and advanced naphtha cracking technologies are described. Section 7 discusses further about catalytic olefin technologies. A glossary of symbols and acronyms used in this paper is given in nomenclature (more abbreviations can be found under Fig. 3).

\section{Background factors}

At least three background factors are relevant for further analysis. These are the role of steam cracking in the industrial sectors, market growth and feedstocks. First, steam cracking and its products, in particular olefins, have a backbone status for many industrial sectors. The worldwide demand and production of olefins are higher than for any other chemicals [9]. Daily goods ranging from computer parts to pharmaceuticals are primarily derived from steam cracking products. In Western Europe, $95 \%$ of ethylene and 70-75\% of propylene are produced through steam cracking [9]. The rest of the propylene comes from refinery fluidized catalytic cracking FCC units $(28 \%)$ and propane dehydrogenation or metathesis (2\%) [9], which will be discussed later. In general, steam cracking plays a dominant role in olefin production.

Second, global ethylene production in the late 1990s has grown at a very high rate of 7-8\% per year. This is largely due to the strong demand growth in East Asia, especially China, while the current market growth in the US and Europe is rather moderate. In the last 2-3 years, the annual growth rate of the global olefin market slowed to 3-4\%. The propylene market is growing faster than the ethylene market by $1-3 \%$. Recently, large plants are being built or planned in the Middle East, but most of them produce ethylene from ethane. Ethane is available at very competitive prices $\$ 0.8-1.3 / \mathrm{GJ}$ in Middle East as opposed to $\$ 4 / G J$ in Asia [10]. This might increase the global share of ethane relative to naphtha in the coming years (see Table 1).

Third, there are two categories of feedstocks for current olefin production. One includes those derived from crude oil, such as naphtha, gas oil, propane, etc. and another includes those derived from natural gas, such as ethane, propane, etc. (see Table 1). Their availability depends on the composition of crude oil and natural gas and their production volumes. Generally in terms of weight, approximately $10 \%$ of oil refinery output is naphtha while $1-14 \%$ of natural gas is ethane and $80-90 \%$ is methane. Natural gas from the Middle East and Norway usually has higher ethane content than that from Russia. These regions together have $80-90 \%$ of the world's natural gas reserves [11].

\footnotetext{
${ }^{4}$ We have completed an analysis of energy use, $\mathrm{CO}_{2}$ emission and production cost for natural gas to olefins (UOP LLC Methanol-to-Olefins, ExxonMobil Methanol-to-Olefins and Lurgi Methanol-to-Propylene) and oxidative coupling of methane via ethane. Our conclusion shows that these new processes are far less efficient than state-of-the-art steam cracking. See details in [8].
} 


\section{Process description of naphtha cracking}

Steam cracking typically refers to all processes inside the battery limits of a steam cracker. As Fig. 1 shows, a steam cracker is comprised of the following three sections: pyrolysis (A), primary fractionation/compression (B) and product recovery/separation (C).

- Pyrolysis section (A). This is the heart of a steam cracker. Naphtha first enters the convection section of a pyrolysis furnace, where a series of heat exchangers are located and it is preheated to $6500^{\circ} \mathrm{C}$. Then, naphtha is vaporized with superheated steam and is passed into long (12-25 m), narrow (25$125 \mathrm{~mm}$ ) tubes, which are made of chromium nickel alloys. Pyrolysis takes place mainly in the radiant section of the furnace, where tubes are externally heated to $750-900{ }^{\circ} \mathrm{C}$ (up to $1100{ }^{\circ} \mathrm{C}$ ) by fuel oil or gas fired burners. Depending on the severity, ${ }^{5}$ naphtha is cracked into smaller molecules via a free-radical mechanism in the absence of catalysts. The free radicals lead to the formation of light olefins in the gaseous state. After leaving the furnace, the hot gas mixture is subsequently quenched in the transfer line exchangers (TLE) to $550-650{ }^{\circ} \mathrm{C}$, or sometimes lower to $400{ }^{\circ} \mathrm{C}$. TLE will then be followed by a series of heat exchangers and temperatures can drop down to $300{ }^{\circ} \mathrm{C}$. These heattransfer activities avoid degradation by secondary reactions and at the same time generate highpressure steam for driving compressors, etc. However, heat exchangers are prone to fouling ${ }^{6}$ and therefore need both scheduled and unscheduled shutdowns.

- Primary fractionation/compression (B). Primary fractionation applies to naphtha and gas oil feed only. In the primary fractionation section, gasoline and fuel oil streams (rich in aromatics) are condensed and fractionated. While this liquid fraction is extracted, the gaseous fraction is desuperheated in the quench tower by a circulating oil or water stream. The gaseous fraction is then passed through four or five stages of gas compression with temperatures at approximately $15-100{ }^{\circ} \mathrm{C}$, then cooling and finally cleanup to remove acid gases, carbon dioxide and water. Most of the dilution steam is condensed, recovered and recycled. Products of this section are fuel oil and BTX, or aromatic gasoline which contains benzene, toluene and xylene. A common problem with compression is fouling in the cracked gas compressors and after-coolers. The build-up of polymers on the rotor and other internals results in energy losses as well as mechanical problems. Wash oil and water are used to reduce fouling.

- Product recovery/fractionation $(C)$. This is essentially a separation process through distillation, refrigeration and extraction. Equipment includes chilling trains and fractionation towers, which include refrigeration, de-methanizer, de-ethanizer and others as shown in Fig. 1. De-methanization requires very low temperatures, e.g. $-114{ }^{\circ} \mathrm{C} . \mathrm{C}_{2}$ compounds, or ethylene and ethane, separation often requires large distillation columns with 120-180 trays and high reflux ratios.

\footnotetext{
${ }^{5}$ High severity (characterized by residence time of less than 0.5 second and temperature up to $900-1100{ }^{\circ} \mathrm{C}$ ) conditions increase ethylene yield (max. 5\% increase) and lowers propylene yield. Low severity has temperatures at lower than $800{ }^{\circ} \mathrm{C}$ and approximately one second residence time [12]. The degree of severity is described by the P/E ratio (propylene/ethylene). A P/E around 0.7 is low severity and any value below 0.5 is high severity. In Western Europe, the average severity for steam crackers is around 0.52 [9]. Severity is strongly limited by metallurgy of the tubes and rapid coking tendency in the coils.

${ }^{6}$ Fouling is a complex science and is still an unresolved problem in the process industry. Simply explained, it is the degradation in heat transfer (or increase in the thermal resistance) due to a build-up of polymers or coke on the heat transfer surface. It also leads to higher hydraulic resistances that result in higher energy use [13].
} 


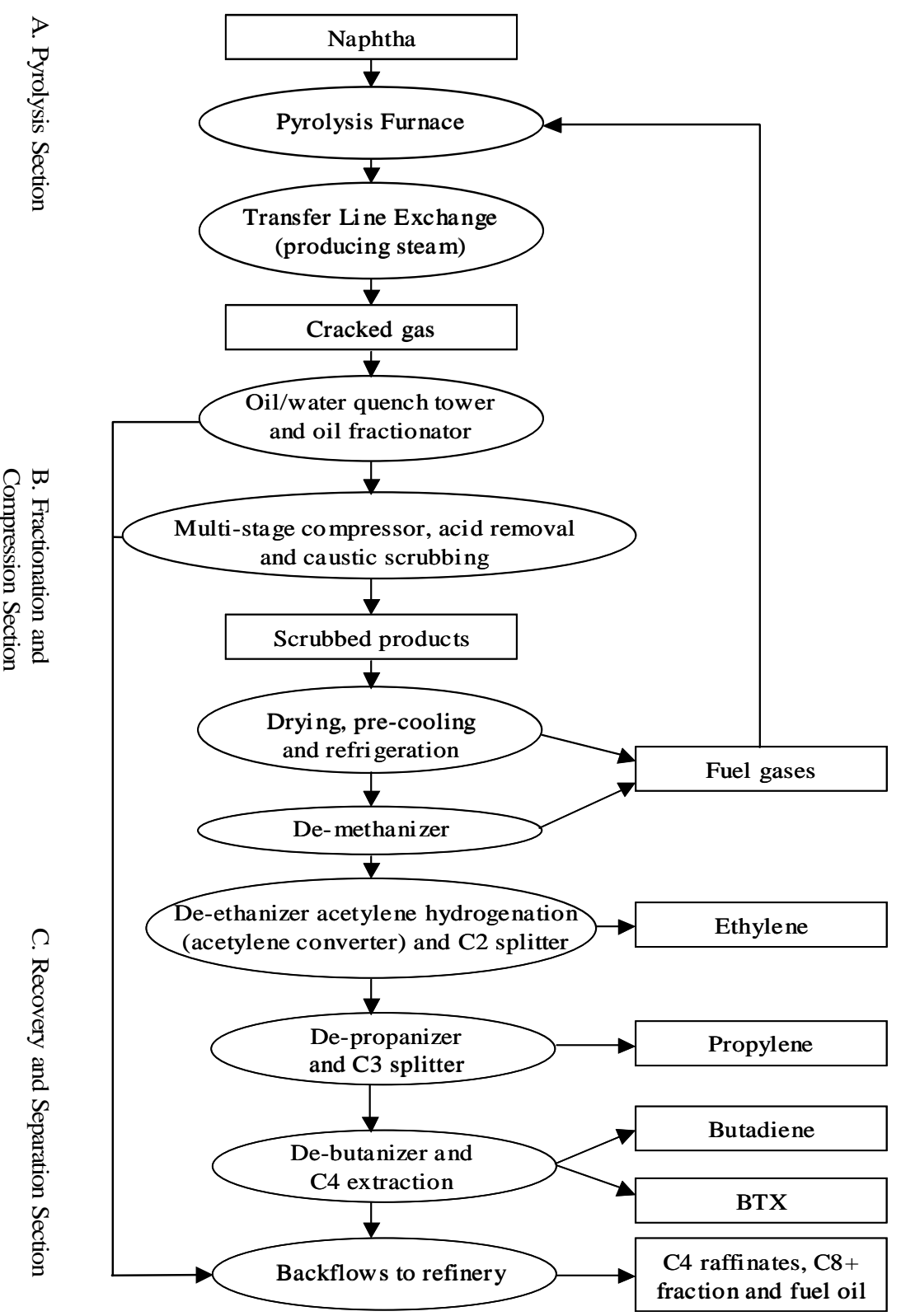

Fig. 1. Typical flow diagram for a naphtha steam cracker (figure was drawn based on $[9,55]$ ).

Undesired acetylene is removed through catalytic hydrogenation or extractive distillation. Similarly, $\mathrm{C}_{3}$ compounds, or propane and propylene, are re-boiled with quench water at approximately $80^{\circ} \mathrm{C}$ and separated in the $\mathrm{C}_{3}$ splitter. Ethylene and propylene refrigeration systems can be operated at low temperatures within -10 and $-150{ }^{\circ} \mathrm{C}$ for cooling and high pressure with 15-30 bar for compression. Ethane and propane are recycled as feedstock. Methane 
and hydrogen are separated at cryogenic temperatures. As fuel grade by-products, they are often used as fuel gas in the pyrolysis process, but they can also be exported. Butadiene, other $\mathrm{C}_{4}$ compounds and aromatic gasoline are separated in the end. The total product yields from naphtha cracking differ depending on the paraffin and aromatic content of the naphtha and on the severities.

Generally, steam cracking of ethane and other feedstocks also requires three sections that are similar to those in the case of naphtha cracking process. However, the processes differ depending on feedstock properties and design arrangement, which often influence fractionation and separation sections. For instance, ethane cracking requires slightly higher temperature in the furnace, a higher capacity of the $\mathrm{C}_{2}$ splitter but less infrastructure facilities. Storage tanks or recovery equipment for propylene, butadiene and BTX aromatics are not needed, but an ethane vaporizer and super-heater are required.

An additional issue is coking. Regular decoking is required in various parts of the pyrolysis section. Before decoking, the furnace has to be shut down. Then, high pressure steam and air are fed to the furnace while it is heated up to $880-900{ }^{\circ} \mathrm{C}$, or even up to $1100{ }^{\circ} \mathrm{C}$. Coke on the inner surfaces of the wall and tubes is either burned off, washed away with high pressure water or removed mechanically. Decoking process can take $20-40 \mathrm{~h}$ for a naphtha steam cracker. Depending on the feedstocks, coil configuration and severity, decoking for steam cracking furnaces is required every 14-100 days on an average. Typically, a naphtha pyrolysis furnace is decoked every 15-40 days. Maximum cycle time is around 60-100 days. Decoking is also required for quench towers, TLEs and other sections.

\section{Definitions}

The total energy use per unit for a specific process is the focus in this paper. It does not include exported energy, such as steam. The total energy use includes energy use in olefin processes and for additional imports if applicable.

Energy use in olefin processes is the sum of fuel, steam and electricity in primary terms that are used for reactions and all the subsequent processes. This definition is referred to as process energy use. Process energy use is usually defined as the energy use in an industrial process. Process energy use is typically expressed in terms of specific energy consumption, or SEC. These two terms are commonly used in the literature to measure the energy efficiency of ethane/naphtha steam crackers. In this paper, the total energy use of steam cracking is the same as its process energy use or SEC, therefore, these three terms are used interchangeably only for steam cracking in this paper.

Process energy use in the case of steam cracking is the sum of energy loss and theoretical thermodynamic energy requirement. Energy loss is the difference between the total energy input and total energy output. The term is used in an economic sense. It refers to the part of energy that is excluded from the total energy output, such as heat loss. Please note that according to the First Law of thermodynamics, energy cannot be lost. Theoretical thermodynamic energy requirement, or endothermicity is the minimum energy input requirement for converting feedstock to desired products in an endothermic reaction such as steam cracking. An illustration is shown in Fig. 2. The figure shows that the endothermicity is $8 \mathrm{GJ} / \mathrm{t}$ ethylene in the case of naphtha cracking specified in the figure. However, since feedstock and product yields of steam cracking vary from process to process, 


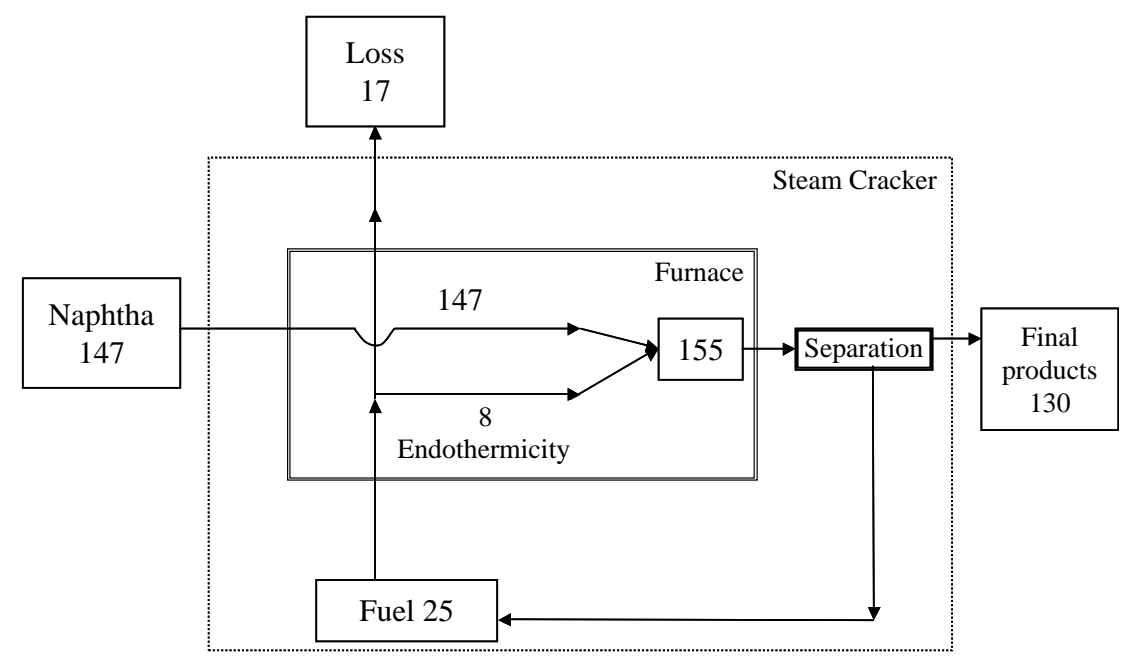

Fig. 2. Energy flow in a typical naphtha steam cracker with the fuel use at $25 \mathrm{GJ} / \mathrm{t}$ ethylene (all values in GJ/t ethylene).

endothermicities vary as well. To compare energy efficiencies of different processes of steam cracking and other olefin technologies, we use process energy use in this paper as defined above.

For non-steam cracking processes addressed in this paper, however, energy use in the olefin process is only part of the total energy use. Some of these processes import oxygen, hydrogen, electricity and/or steam. Primary energy use in the production of these imports is also accounted as part of the total energy use. These energy uses are expressed in SEC as well.

All energy figures are in primary energy terms. Final energy figures for electricity and steam have been converted to primary energy using efficiency factors of 40 and $85 \%$, respectively. Energy use in catalyst and equipment production is not included. Energy contents of products, or calorific values, are calculated based on their lower heating value (LHVs) [14].

The degree of energy efficiency is measured by SEC in GJ/t. This paper uses several measures of SEC, e.g. GJ/t feedstock, GJ/t ethylene or GJ/t high value chemicals (HVCs). In this paper, GJ/t ethylene means that all energy use is allocated to ethylene only and all other by-products are hence produced 'for free' in terms of energy use. This is not always the best indicator. For example, if ethane cracking is compared with naphtha cracking, it will not be fair to use GJ/t ethylene for comparison. Ethylene yield from ethane cracking is much higher than from naphtha cracking, but naphtha cracking also yields considerable amounts of other valuable by-products (see Table 2). For this reason, GJ/t HVCs is chosen in this paper as the primary indicator. HVCs include light olefins and non-olefins. Light olefins are ethylene, propylene and butadiene. Non-olefins are aromatics and other $\mathrm{C}_{5}+$ compounds in the case of steam cracking. While the mass of light olefins is fully taken into account, the mass of non-olefins is weighted by $50 \%$. The reason is that these non-olefin products usually have half of the economic value of light olefins. Our definition is different from the definition of HVCs used in [9], where ethylene, propylene, butadiene, benzene and hydrogen are weighted by $100 \%$. However, this does not lead to large differences in terms of SECs since the yield of non-olefins from steam cracking is small. Our definition of HVCs is useful to compare steam cracking with alternatives. For example, catalytic cracking has high aromatics yield at 15-30\% (see Table 5). Our estimates for energy savings refer to savings on the total energy use in terms of GJ/t HVCs. 
Table 2

Overview of the two currently most used feedstocks in olefins production

\begin{tabular}{|c|c|c|}
\hline & Ethane & Naphtha \\
\hline SEC $(G J / t \text { ethylene })^{\mathrm{a}}$ & 17-21 (typical) and 15-25 (maximum) & 26-31 (typical) and 20-40 (maximum) \\
\hline SEC (GJ/t HVCs) & 16-19 (typical) & 14-17 (typical) \\
\hline $\mathrm{CO}_{2}$ emission ( $\mathrm{CO}_{2} /$ t ethylene $)^{\mathrm{b}}$ & $1.0-1.2$ (typical) & $1.8-2.0$ (typical) \\
\hline $\mathrm{CO}_{2}$ emission $\left(\mathrm{t} \mathrm{CO}_{2} / \mathrm{t} \mathrm{HVCs}\right)$ & $1.0-1.2$ & $1.6-1.8$ \\
\hline Ethylene yield $(\mathrm{wt} \%)^{\mathrm{c}}$ & $80-84$ & 29-34 (30\% typical) \\
\hline Propylene yield (wt\%) & $1-1.6$ & $13-16$ \\
\hline Butadiene yield (wt $\%$ ) & $1-1.4$ & $4-5$ \\
\hline Aromatics and $\mathrm{C} 4+$ yield (wt $\%)$ & $2-3$ & $10-16$ \\
\hline HVCs yield (wt\%) & 82 (typical) & 55 (typical) \\
\hline $\begin{array}{l}\text { Methane yield (not counted as HVCs) } \\
\text { (wt } \% \text { ) }\end{array}$ & 4.2 & $13-14$ \\
\hline $\begin{array}{l}\text { Hydrogen yield (not counted as } \\
\text { HVCs) (wt } \% \text { ) }\end{array}$ & 4.3 & 1 \\
\hline $\begin{array}{l}\text { Backflows to refinery (not counted as } \\
\text { HVCs) (wt } \% \text { ) }\end{array}$ & 0 & $9-10$ \\
\hline $\begin{array}{l}\text { Losses (due to fouling, coking, etc.) } \\
\text { (wt\%) }\end{array}$ & $1-2$ & $1-2$ \\
\hline
\end{tabular}

${ }^{a}$ Energy use is based on [19,21]. SEC here only refers to process energy use in pyrolysis and separation.

b Emissions are calculated based on [21,67]. Emissions are the result of fuel combustion and utilities, both of which use fossil fuel. Ethane cracking results in higher hydrogen and ethylene content, therefore less $\mathrm{CO}_{2}$ emission per ton of ethylene, than naphtha cracking does.

${ }^{c}$ Yield data is based on [21,22]. Yields are on mass basis and are all final yields.

In addition, this paper combines and analyzes the results of exergy analyses of the naphtha cracking process based on the data from two sources. The exergy of a system is commonly defined as the maximum amount of work that is obtainable when the system is brought into equilibrium with the reference state [15]. Unlike energy, exergy can be lost according to the Second Law of Thermodynamics. Definitions, reference state and equations used in the two sources are described in the sources themselves or in the references quoted by these two sources $[16,17]$. For the calculation of the exergy value of each material flow $E_{\mathrm{m}}$, both sources used the formula $E_{\mathrm{m}}=h-h_{0}-T_{0}\left(s-s_{0}\right)$. $h_{0}$ is the reference enthalpy, $h$ is enthalpy of the flow, $s_{0}$ is the reference entropy, $s$ is the entropy of the flow. The reference conditions are the standard ambient conditions, i.e. temperature $T_{0}$ at $25^{\circ} \mathrm{C}$ and pressure at $1 \mathrm{bar}$. The exergy values of the air, water and $\mathrm{CO}_{2}$ are assumed as 0 . The full details of calculations can be found in $[16,17]$. In this paper, we try to identify the locations of exergy losses so as to find out in which process significant exergy savings could be possible.

All $\mathrm{CO}_{2}$ emissions from the use of fuel-grade by-products and external energy sources are counted. In this paper, yield refers to final yield after separation, recycling, etc. It is defined as a percentage of desired products divided by hydrocarbon feedstock on the mass basis, unless otherwise specified. Chemistry literature often uses per-pass yield on the mol basis.

\section{Energy analysis of naphtha/ethane cracking}

In this section, a typical specific energy consumption level for the comparison of the total energy use in steam cracking will be set. Then, a breakdown of energy uses and exergy 
loses in a typical naphtha steam cracker will be presented. Finally, energy integration will be discussed.

\subsection{Typical specific energy consumption}

There is little data in the public literature on the specific energy consumption SEC that represents current process energy use by a typical existing naphtha steam cracker. Most data available are in SECs in terms of GJ/t ethylene and do not give further data on yields and methodologies. They are rather old, incomplete or within a very wide range. The world average SECs, excluding Japan and Korea, ${ }^{7}$ in 1995 was approximately 30-36 GJ/t ethylene for naphtha steam crackers [18]. If one assumes an efficiency improvement rate of $1.7 \%$ per year for typical steam crackers in the past 30 years [9] and typical yields of HVCs in Table 2, then the SECs for a typical naphtha steam cracker should be approximately within the range of 26-31 GJ/t ethylene and 14-17 GJ/t HVCs.

As defined earlier, the SEC in the case of naphtha cracking is the sum of theoretical thermodynamic energy requirement and energy loss. Fig. 2 shows that the theoretical thermodynamic energy requirement for naphtha cracking is approximately $8 \mathrm{GJ} / \mathrm{t}$ ethylene or approximately $5 \mathrm{GJ} / \mathrm{t}$ HVCs. This is roughly a third of the total SEC in the naphtha cracking as shown in Fig. 2 and Table 2. The other two-thirds of the SEC, approximately $17 \mathrm{GJ} / \mathrm{t}$ ethylene or $8 \mathrm{GJ} / \mathrm{t} \mathrm{HVCs}$, is energy loss. In the case of naphtha cracking as specified in Table 3, the value of the total exergy losses is also $17 \mathrm{GJ} / \mathrm{t}$ ethylene.

\subsection{Breakdown of SEC and exergy losses}

The breakdown of SEC and exergy losses by each process helps to identify in which process significant energy saving are possible. Data for a breakdown of SEC and exergy losses found in literature are summarized in Table 3. Regarding energy analysis, pyrolysis accounts for approximately $2 / 3$ of the total SEC of naphtha steam crackers. The remaining $1 / 3$ is consumed in compression and separation sections. The compression section uses approximately $15 \%$ of the total energy use in naphtha cracking. This is slightly less than the energy use in the separation section, which is approximately $1 / 5$ of the total energy use in naphtha cracking.

Regarding exergy analysis, approximately $75 \%$ of the total exergy losses occurs in the pyrolysis section. Fuel combustion is predictably the main cause. These large exergy losses can be illustrated by the high temperature drops across heat exchangers, which are mostly in the range of $100-300{ }^{\circ} \mathrm{C}$ and even near $500{ }^{\circ} \mathrm{C}$ in the TLEs. Throughout the whole pyrolysis process, the total temperature drop is more than $1100{ }^{\circ} \mathrm{C}$ and the total pressure drop is nearly 70 bar.

With respect to exergy use in other sections of naphtha steam crackers, most significant losses occur in propylene refrigeration, de-ethanization/ $\mathrm{C}_{2}$ splitter and compression. Losses in the compression and separation sections are mainly caused by the use of electricity for refrigeration and compression, whose production is known for significant exergy loss. These losses are not surprising if we consider the conditions in the separation and compression sections. As the process description has indicated, most of

\footnotetext{
${ }^{7}$ The SECs of naphtha steam crackers in Japan and Korea in 1995 are exceptionally low, namely approximately 25 GJ/t ethylene [18]. About $40 \%$ of steam crackers in Europe have SECs at approximately 31-35 GJ/t ethylene [9]. Naphtha and gas oil steam crackers in the US have SECs at approximately $32 \mathrm{GJ} / \mathrm{t}$ [19].
} 
Table 3

Breakdown of specific energy consumption (SEC) and exergy losses in the steam cracking process

\begin{tabular}{|c|c|c|c|c|c|c|c|}
\hline & & \multicolumn{2}{|l|}{ Ethane } & & \multicolumn{3}{|l|}{ Naphtha } \\
\hline & & \multirow{2}{*}{$\begin{array}{l}\mathrm{SEC}^{\mathrm{a}} \\
{[20]}\end{array}$} & \multirow{2}{*}{$\begin{array}{l}\text { SEC } \\
{[68]}\end{array}$} & & \multicolumn{3}{|l|}{ Exergy loss } \\
\hline & & & & & Our estimate $^{b}$ & {$[16]$} & {$[17,69]$} \\
\hline \multirow[t]{2}{*}{ Pyrolysis } & $\begin{array}{l}\text { Heat of } \\
\text { reaction }\end{array}$ & $23 \%^{\mathrm{c}}$ & $65 \%$ & $\begin{array}{l}\text { Fuel combustion } \\
\text { and heat transfer to } \\
\text { the furnace }\end{array}$ & $\begin{array}{l}75 \% \text { (or } \\
15 \mathrm{GJ} / \mathrm{t} \\
\text { ethylene) }\end{array}$ & $73 \%$ & Not applicable \\
\hline & $\begin{array}{l}\text { Steam, } \\
\text { heating and } \\
\text { losses }\end{array}$ & $24 \%$ & & $\begin{array}{l}\text { Heat exchange with } \\
\text { steam, TLEs and } \\
\text { heat loss to flue gas }\end{array}$ & & $27 \%$ & \\
\hline $\begin{array}{l}\text { Fractionation } \\
\text { and com- } \\
\text { pression }\end{array}$ & & $22 \%^{\mathrm{d}}$ & $15 \%{ }^{\mathrm{e}}$ & $\begin{array}{l}\text { Fractionation }^{\mathrm{f}} \text { and } \\
\text { compression }\end{array}$ & $\begin{array}{l}25 \%(2 \mathrm{GJ} / \mathrm{t} \\
\text { ethylene in } \\
\text { compression } \\
\text { and the rest of } \\
\text { separation } \\
\text { processes) }\end{array}$ & $\begin{array}{l}\text { Not appli- } \\
\text { cable }\end{array}$ & $19 \%$ \\
\hline \multirow[t]{6}{*}{ Separation } & & $31 \%$ & $20 \%$ & De-methanization & & & $12 \%$ \\
\hline & & & & $\begin{array}{l}\text { De-ethanizer and } \\
\mathrm{C}_{2} \text { splitter }\end{array}$ & & & $23 \%$ \\
\hline & & & & $\mathrm{C}_{3}$ splitter & & & $2 \%$ \\
\hline & & & & $\begin{array}{l}\text { De-propanization/ } \\
\text { De-butanization }\end{array}$ & & & $10 \%$ \\
\hline & & & & $\begin{array}{l}\text { Ethylene refriger- } \\
\text { ation }\end{array}$ & & & $5 \%$ \\
\hline & & & & $\begin{array}{l}\text { Propylene refriger- } \\
\text { ation }\end{array}$ & & & $30 \%$ \\
\hline $\begin{array}{l}\text { Total process } \\
\text { energy use }\end{array}$ & & $100 \%$ & $100 \%$ & Total exergy losses & $\begin{array}{l}100 \% \text { or } \\
17 \mathrm{GJ} / \mathrm{t} \\
\text { ethylene }\end{array}$ & $\begin{array}{l}100 \% \text { (only } \\
\text { pyrolysis } \\
\text { section) }\end{array}$ & $\begin{array}{l}100 \% \text { (only } \\
\text { compression } \\
\text { and separ- } \\
\text { ation) }\end{array}$ \\
\hline
\end{tabular}

${ }^{\text {a }}$ All energy figures in the table are in primary energy terms. Generally speaking, the contribution of electricity is very small, approximately $1 \mathrm{GJ} / \mathrm{t}$ ethylene [19]. Steam is produced internally and is in balance. Almost all process energy (including steam) originates from combustion of fuel-grade by-products and extra fuel (only in case of ethane cracking). The distribution of byproduct/fuel energy contents is represented by the percentages in the table.

${ }^{\mathrm{b}}$ Our estimate on the pyrolysis section is based on [16]. Our estimate on the compression and separation sections is based on $[17,69]$.

c Another figure for heat of reaction given in [6] is $21 \%$. Energy use for 'heat of reaction' refers to the energy used to convert feedstocks into desired products.

$\mathrm{d}$ Another figure for compression given in [6] is $16 \%$.

e Another figure for compression given in [6] is $13 \%$.

${ }^{\mathrm{f}}$ Data on the exergy loss in fractionation and quench towers was not found. We roughly estimated the exergy loss here is below $0.2 \mathrm{GJ} / \mathrm{t}$ ethylene.

the conditions for refrigeration are cryogenic: low temperatures (as low as $-150{ }^{\circ} \mathrm{C}$ ) and high pressure (up to 30 bar).

Ethane cracking has a similar distribution of energy consumption. However, an important difference with naphtha cracking is that the contribution of SEC in the pyrolysis section of ethane cracking 
(approximately 1/2) is less than that (approximately 2/3) in the case of naphtha cracking. In turn, the contribution of SEC in the compression and separation sections is slightly higher in the case of ethane cracking than that in the case of naphtha cracking. The chiller that condenses and separates ethylene and ethane uses up to approximately $21 \%$ of the total energy consumption [20]. As mentioned in the process description, ethylene and ethane have similar boiling points, which causes the separation to be very energy-consuming.

As mentioned in the process description of steam cracking, additional energy used in decoking/defouling, shutdowns/restarts and related maintenance for various sections of a steam cracker could account for approximately 1-2\% of the total energy use. This additional energy use in decoking and defouling is usually not counted as part of the SEC in steam cracking. Shutdowns also lead directly to large monetary losses. Therefore, it is not surprising to hear that the greatest challenge for steam-cracker engineers today is to improve the on-stream factors, or intervals between shutdowns, by reducing coke formation and to extend furnace life between tube replacements.

\subsection{Energy integration}

In the case of naphtha cracking, process energy used in the pyrolysis section is provided through combusting significant volumes of fuel gases, which are fuel-grade by-products. These by-products, together with flue gases and waste heat, can meet approximately $95 \%$ of process energy demand in naphtha steam crackers. These fuel-grade by-products amount to approximately 20-25\% of the energy content of naphtha. The LHV of naphtha is approximately $44 \mathrm{GJ} / \mathrm{t}$. Energy for the compression and separation sections is provided by steam, almost all of which is produced in the TLEs. Typically, steam is in balance, which means that there is no net steam import or export. A small amount of electricity is provided from external sources. Electricity is used primarily for running cooling water, quench oil pumps and methane compressors. It amounts to approximately $1 \mathrm{GJ} / \mathrm{t}$ ethylene. Backflows to the refinery and energy export together can amount up to approximately 9-10 GJ/t ethylene for naphtha cracking [19]. In contrast to naphtha cracking, ethane cracking is not self-sufficient in terms of energy and therefore requires energy import, which is $15 \%$ of the total SEC through various energy carriers [21].

\section{Latest developments of naphtha cracking}

After we identified the processes where energy and exergy losses occur and understood the energy integration, we are now able to study processes that can reduce these losses. We first look at the latest development of steam cracking. A family portrait of olefin technologies sorted by feedstocks is drawn (Fig. 3). A number of the latest technologies are chosen using the following criteria: using conventional or heavy feedstocks, undergoing active research and being highly visible in recent publications, recently emerging or being commercialized and possibly having significant impacts on energy use. In the following sections, these technologies will be divided into two categories: state-ofthe-art naphtha cracking processes (Table 4); advanced technologies in specific sections of naphtha cracking. 


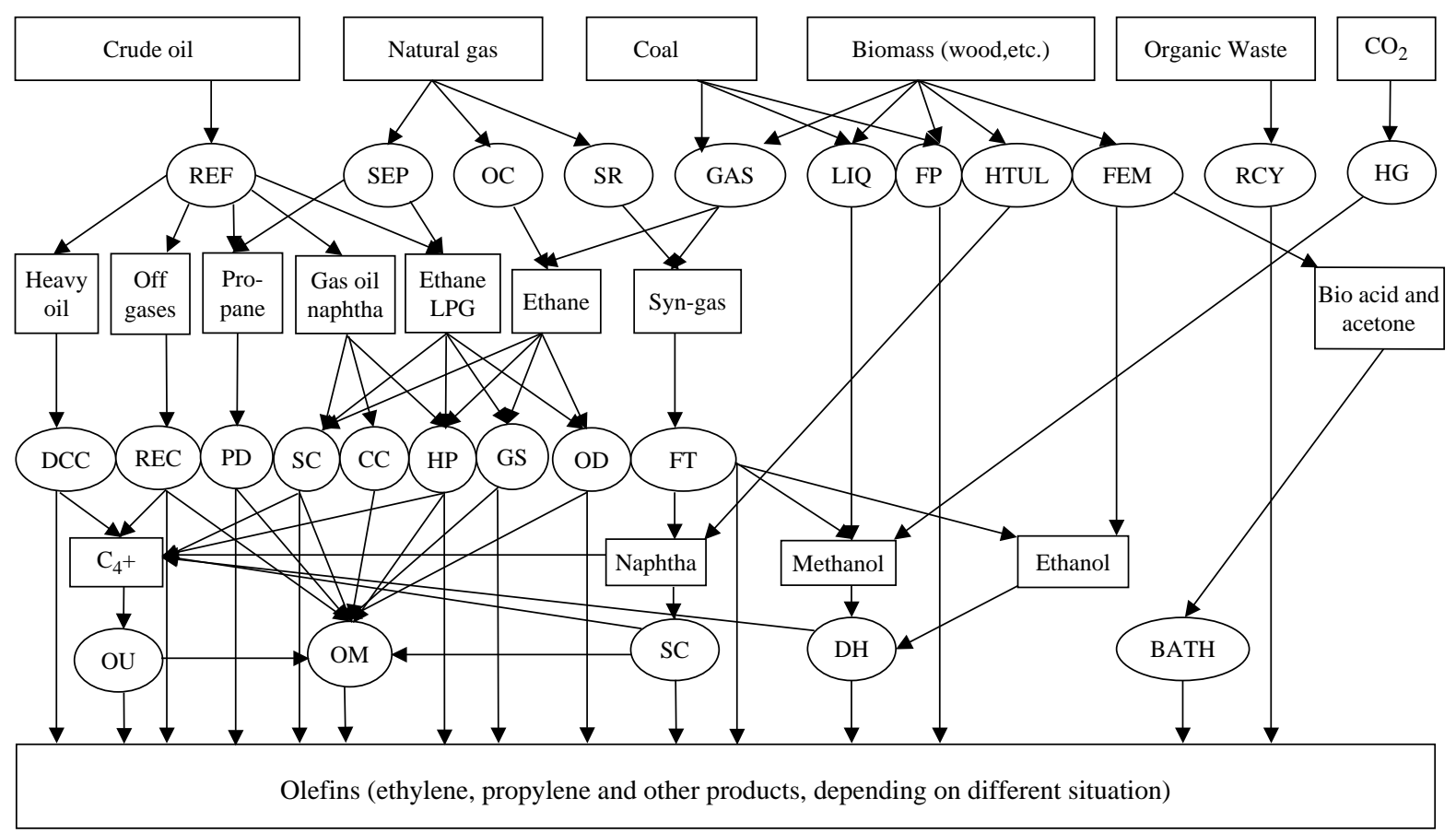

BATH: $\quad$ Bio-acid acetone to hydrocarbons (e.g. olefins) [5];

CC: $\quad$ Catalytic Cracking or Catalytic Pyrolysis;

DCC: $\quad$ Deep Catalytic Cracking, etc. (see Table 5);

DH: $\quad$ De-hydration process (e.g. methanol to olefins, methanol to propylene and ethanol dehydration) $[12,56]$;

FM: $\quad$ Fermentation [57, 58]:

FP: $\quad$ Flash pyrolysis, sometimes in the presence of methane [58];

FT: $\quad$ Fischer-Tropsch synthesis (using syngas $\mathrm{CO}$ and $\mathrm{H}_{2}$ mixture to synthesize methanol or other products) [5];

GAS: $\quad$ Gasification and liquefaction $[5,57]$;

GS: $\quad$ Gas stream reactor technologies, e.g. shockwave reactors (Table 5)

HG: $\quad$ Hydrogenation [5, 57];

HP: $\quad$ Hydro-Pyrolysis (see Table 5);

HTUL: $\quad$ Hydro-Thermal Upgrading Liquefaction which produces naphtha from biomass feedstock [5, 57];

OC: Oxidative coupling of methane via ethane [5];

OD: $\quad$ Oxidative Dehydrogenation of ethane [5];

OM: $\quad$ Olefin Metathesis, e.g. ABB-Lummus Olefin Conversion Technology, IFP-CPC meta-4 [59];

OU: $\quad$ Olefins Upgrading (conversion of $\mathrm{C}_{4^{-}} \mathrm{C}_{10}$ ) to light olefins, e.g. Superflex [60], Propylur [61] and Olefins Cracking [44].

PD: $\quad$ Propane dehydrogenation [62, 63];

RCY: $\quad$ Re-cycling pyrolysis using organic waste, such as discarded plastics, used rubber, etc.[5, 57];

REC: $\quad$ Recovery of refinery off gases, which contains ethylene, propylene, propane, etc. [57];

REF: Refinery processes. Distillation of crude oil produces naphtha and heavy oil. Catalytic cracking produces off gases. Cryogenic separation and absorption produces ethane and LPG;

SC: $\quad$ Steam cracking (conventional);

SEP: $\quad$ Gas separation process which produces methane, ethane and propane;

SR: $\quad$ Steam Reforming of natural gas to produce methanol.

Fig. 3. (A) Family portrait of olefin technologies: current and future (abbreviations used in Fig. 3) (more abbreviations can be found in nomenclature). 
Table 4

State-of-the-art naphtha cracking technologies sorted by licensors

\begin{tabular}{|c|c|c|c|c|c|}
\hline Licensors & Technip-Coflexip $^{a}$ & ABB lummus ${ }^{b}$ & Linde $A G^{c}$ & $\begin{array}{l}\text { Stone and } \\
\text { webster }^{\mathrm{d}}\end{array}$ & $\begin{array}{l}\text { Kellogg Brown } \\
\& \operatorname{Root}^{\mathrm{e}}\end{array}$ \\
\hline $\begin{array}{l}\text { Coil related furnace } \\
\text { features }\end{array}$ & $\begin{array}{l}\text { Radiant coils pre- } \\
\text { treated to reduce } \\
\text { coking with a sulfur- } \\
\text { silica mixture }\end{array}$ & $\begin{array}{l}\text { Double pass } \\
\text { radiant coil } \\
\text { design; online } \\
\text { decoking } \\
\text { reduces emis- } \\
\text { sions }\end{array}$ & $\begin{array}{l}\text { Twin-radiant- } \\
\text { cell design } \\
\text { (single split) is } \\
13 \mathrm{~m} \text { (shorter } \\
\text { than the average } \\
\text { length } 25 \mathrm{~m} \text { ) }\end{array}$ & $\begin{array}{l}\text { Twin-radiant- } \\
\text { cell design and } \\
\text { quadra-cracking }\end{array}$ & $\begin{array}{l}\text { Coil design } \\
\text { (straight, small } \\
\text { diameter), low } \\
\text { reaction time; } \\
\text { very high sever- } \\
\text { ity }\end{array}$ \\
\hline $\begin{array}{l}\text { De-methanizer } \\
\text { separation features }\end{array}$ & $\begin{array}{l}\text { Double de-methaniz- } \\
\text { ing stripping system }\end{array}$ & $\begin{array}{l}\text { De-methanizer } \\
\text { with low } \\
\text { refrigeration } \\
\text { demand }\end{array}$ & $\begin{array}{l}\text { Front-end de- } \\
\text { methanizer and } \\
\text { hydrogenation }\end{array}$ & $\begin{array}{l}\text { De-methaniza- } \\
\text { tion simul- } \\
\text { taneous mass } \\
\text { transfer and heat } \\
\text { transfer }\end{array}$ & $\begin{array}{l}\text { Absorption- } \\
\text { based demetha- } \\
\text { nization system } \\
\text { with front-end } \\
\text { design }\end{array}$ \\
\hline Gas turbine & No data found & $\begin{array}{l}\text { Approximately } \\
3 \mathrm{GJ} / \mathrm{t} \text { ethylene } \\
\text { saved }\end{array}$ & No data found & $\begin{array}{l}\text { Offered but no } \\
\text { data }\end{array}$ & No data found \\
\hline Ethylene yield (wt\%) & $35 \%$ & $34.4 \%$ & $35 \%$ & No data found & $38 \%$ \\
\hline SEC (GJ/t ethylene $)^{f}$ & $\begin{array}{l}18.8-20 \text { (best) } \\
\text { or } 21.6-25.2 \\
\text { (typical) }\end{array}$ & $\begin{array}{l}18 \text { (with gas } \\
\text { turbine); } 21 \\
\text { (typical) }\end{array}$ & 21 (best) & $20-25$ & No data found \\
\hline
\end{tabular}

For the conventional naphtha cracking, ethylene yield is typically $30 \%$. HVCs yield is typically $55 \%$.

a Technip data come from [22]. According to Technip, SECs vary depending on the processing scheme, extent of heat integration and climatic conditions.

b ABB data come from [22]. Other yields are $14.4 \%$, butadiene $4.9 \%$ and aromatics $14 \%$. The total HVCs yield is $60.7 \%$. Gas turbine data based on [30].

c Linde data come from [22].

d Stone and Webster data come from [22].

e Kellogg Brown \& Root come from [22].

f The average SEC in the industry today is around 26-31 GJ/t ethylene for naphtha cracking.

\subsection{State-of-the-art naphtha cracking ${ }^{8}$}

Table 4 is a summary of state-of-the-art technologies for naphtha cracking sorted by licensors. Table 4 contains only publicly available information. For the separation section, only information on the demethanization was available for each licensor. Regarding pyrolysis furnaces, most technologies focus on the design optimization of furnace coils, which are located in the radiant section, where cracking occurs (see process description in Section 4). The goal is to improve heat transfer, raise severity, minimize coking and maximize olefin yields. As Table 4 shows, small, double coils and double radiant cells seem to be common features. With respect to improvements in the separation processes, front-end demethanization reduces refrigeration needs and therefore energy demand. For example, ABB Lummus claims a 75\% cut in refrigeration needs [22]. However, traditional energy-consuming refrigeration and

\footnotetext{
${ }^{8}$ State-of-the-art technologies are technologies that are offered as standard, widely accepted processes and would be used if a new plant is to be built nowadays. For example, those process introduced in the 'petrochemical processes 2003' in [22], which are commonly offered by licensors.
} 
distillation as the main separation method remain unchanged. Further, no significant changes in the subsequent sections, such as compression and $\mathrm{C}_{2}, \mathrm{C}_{3}$ and $\mathrm{C}_{4}$ separation, are reported as part of state-ofthe-art naphtha cracking technologies.

The processes in Table 4 could reach SECs in the range of approximately 18-25.2 GJ/t ethylene, which is equivalent to savings of approximately $20 \%$ on current average SEC (26-31 GJ/t ethylene). The gas turbine mentioned in Table 4 is not commonly offered by every licensor. It will be discussed again in Section 6.2. Without considering gas turbines, an average SEC for state-of-the-art naphtha cracking is approximately 20-25 GJ/t ethylene and 11-14 GJ/t HVCs. HVC yields used in the calculation are based on data reported by ABB Lummus. ${ }^{9}$ The SEC figures (11-14 GJ/HVCs) for state-of-the-art naphtha cracking technologies are still far more than the absolute theoretical thermodynamic energy requirement for naphtha to olefin conversion mentioned earlier (5 GJ/HVCs).

In addition to data given in Table 4, a trend can be observed that the sizes of state-of-the-art crackers are increasing. While the current average steam cracker has capacity of around 500,000 t ethylene per year [9], new naphtha steam crackers can produce over one million tons of ethylene annually. Technip built a plant with an ethylene capacity of over 1.2 million tons of ethylene per year in Iran [23]. KBR (Kellogg Brown and Root) claims that they can be able to build a two-million tpa ethylene plant [24]. The same trend is observed for ethane crackers. Stone and Webster built an ethane cracker for NOVA in Canada with a capacity of 1.27 million tons of ethylene per year. Technip claims the SEC of their crackers is $20 \mathrm{GJ} / \mathrm{t}$ ethylene as opposed to an average $30 \mathrm{GJ} / \mathrm{t}_{\text {ethylene }}{ }^{10}$ [23].

\subsection{Advanced naphtha cracking technologies}

Advanced technologies in specific sections of a naphtha steam cracker are not being offered by major licensors as part of standard commercialized processes. In fact, some of them are commercially available, but due to high costs, most of them are not yet widely implemented. Others are new and their technical and economic feasibility are yet to be proven. Nevertheless, these new technologies have potentials to reduce energy use in specific sections of steam cracking, where energy and exergy losses occur.

With respect to the pyrolysis section, there are a few significant innovations and all of them are aimed at improving heat transfer and raising severity. There are circulating solids such as sand, coke and other carriers, circulating beds [25], selective radiant coils to allow better control of the propylene/ethylene ratio [26], ceramic-coated tubes/coils and other advanced furnace materials [27,28]. Here, only advanced furnace materials are discussed. Reducing coking can greatly improve heat transfer in furnaces. Traditionally, coking can be partially inhibited by a sulfur compound-based chemical treatment of inner walls of tubes/coils. Advanced tubes and coils in various shapes such as cast-fins are coated with ceramics such as aqueous salt metals, silicon and phosphorus compounds. They do not need chemical treatment. Coating can also have catalytic effects for olefins selectivity. Also, coating could allow higher severity and thereby enhance ethylene yields. Sintered silicon carbide (SiC) ceramics, for

\footnotetext{
${ }^{9}$ ABB Lummus' steam cracking technology is said to be used by over $40 \%$ of the world's olefin plants [22].

${ }^{10}$ Technip also claims that their mega crackers have lower product losses which is $0.25 \%$ in comparison with an average of $1 \%$ and lower $\mathrm{CO}_{2}$ emission which is half of the average $1.6 \mathrm{t} / \mathrm{t}$ ethylene in Table 2 and lower operational cost advantages because of economy of scale [23]. It also claims that the maximum capacity cannot exceed one million tons of ethylene due to the limits of compressors.
} 
instance, offer maximum temperature up to $1400{ }^{\circ} \mathrm{C}$, high conductivity and low surface catalytic activity [29]. Conventional pyrolysis tubes made of $\mathrm{Cr}-\mathrm{Ni}$ alloys allow the maximum skin temperature only up to $1100{ }^{\circ} \mathrm{C}$. It is estimated that these advanced materials could lead to up to approximately $10 \%$ savings on current average SEC, or approximately 2-3 GJ/t ethylene [26].

An additional new technology is gas turbine integration. Gas turbine integration results in the export of both steam and electricity. Also, it produces hot combustion gas for feedstock heating in a pyrolysis furnace. It can possibly save $13 \%$ (approximately $3 \mathrm{GJ} / \mathrm{t}$ ethylene) on the SEC of state-of-the-art steam cracking technologies [30]. If both advanced furnace materials and gas turbine integration are applied, approximately $20 \%$ energy savings (approximately $4 \mathrm{GJ} / \mathrm{t}$ ethylene) on the SEC of state-of-the-art naphtha cracking is possible.

With respect to the compression and separation section, possible improvements are: Vacuum Swing Adsorption Process (VSA), mechanical vapor recompression (MVR), advanced distillation columns, membrane and combined refrigeration systems. VSA uses solid sorbents for selective adsorption of ethylene and propylene over paraffins, such as ethane and propane. MVR could be used in a conventional propane/propylene splitter. It can lead to approximately 5\% (approximately $1 \mathrm{GJ} / \mathrm{t}$ ethylene) savings on the SEC of state-of-the-art steam cracking [31].

Advanced distillation column technology has been studied since the 1930s. One type of such columns is 'divided-wall' distillation columns for butadiene extraction. They could save approximately $16 \%$ on the SEC in the conventional butadiene distillation section [32]. Another type of such advanced distillation columns is the Heat Integrated Distillation Column (HIDiC). Two variations of HIDiC developed in the Netherlands are called Plate Fin and Concentric. These advanced columns improve heat transfer by building heat exchangers between the stripping and rectifying sections. They can be applied in the ethylene/ethane and the propylene/propane splitter. It is generally estimated that HIDiC saves approximately 60-90\% energy, or $0.1-0.3 \mathrm{GJ} / \mathrm{t}$ ethylene on the SEC of a conventional propylene/propane distillation column, which is known for poor energy efficiency (approximately 20-30\%) [33,34]. With HIDiC, it is even possible to save approximately $50 \%$ (approximately $0.15 \mathrm{GJ} / \mathrm{t}$ ethylene) on the SEC in modern distillation columns with heat pumps.

Membranes are rarely applied in steam cracking. Membrane materials are often made of polymer or inorganic materials. Membranes can possibly be applied in separation of olefin/paraffin, gases (hydrogen recovery ${ }^{11}$, acids, etc.) and coke/water [36]. Membranes could combine high selectivity with high permeability. With regard to membrane application in the $\mathrm{C}_{2}$ and $\mathrm{C}_{3}$ separation alone, approximately $8 \%$ (1.5 GJ/t ethylene) savings on process energy are expected [37]. However, membrane separation is widely believed to be as an immature technology because membranes are unable to withstand severe operating conditions and need regular replacement due to erosion, etc. Therefore, membranes are not yet licensed by any steam cracking licensors.

Energy integration of a steam cracker with another industrial process can also save energy. Combined refrigeration synchronizes the cryogenic natural gas liquid plant, natural gas liquid fractionation and ethylene plants into a single unit [38]. It is claimed that the total refrigeration requirement by an ethylene plant is reduced by $60-80 \%$, or approximately $1 \mathrm{GJ} / \mathrm{t}$ ethylene can be saved [38].

\footnotetext{
${ }^{11}$ Hydrogen recovery could be among the first wide-scale commercial applications of membranes [35].
} 
Since some of the technologies mentioned above could be applied in the same process and most of them are not yet mature, it is not possible to simply add up all the energy savings. Considering the distribution of SEC described in Table 3, advanced steam cracking technologies could lead to up to approximately $15 \%$ energy savings altogether (approximately $3 \mathrm{GJ} / \mathrm{t}$ ethylene) on the SEC of state-ofthe-art steam cracking.

\section{Catalytic and other alternative technologies}

\subsection{Energy use}

Catalytic and other alternative olefin technologies can process conventional or heavy feedstocks and are therefore alternatives to conventional steam cracking. Table 5 is a list of these technologies in the order of feedstock weight from light (left) to heavy (right). Note that the technologies in Table 5 differ only from the pyrolysis furnace of a steam cracker. The rest, including compression and separation sections, are assumed to be similar to those of state-of-the-art steam cracking. The first three technologies use gas feedstocks. Gas stream technologies use gases as heat carriers to provide enthalpy needed for pyrolysis [39]. Shockwave technology uses steam at supersonic speed as heat carrier and the process is volumetric, not limited by heat transfer through metal walls and tubes as for the conventional steam cracking. If primary energy use for steam production is included, the total energy use of shockwave technology is approximately $45 \%$ less than the SEC of state-of-the-art steam cracking [40]. Olefin producers are very concerned about the overall system complexity that result from large requirements of steam (approximately 5-10 times of the steam requirement by conventional steam cracking) and subsequent energy recovery from waste steam [41]. R\&D on shockwave technology was stopped in 1998.

There are two oxidative dehydrogenation processes, both for processing gas feedstocks. Both processes require high-purity approximately $90 \%$ oxygen. Ethane oxidative dehydrogenation results in approximately 35\% potential saving (including primary energy use in oxygen production) on the SEC of state-of-the-art ethane cracking [42]. However, if the $\mathrm{CO}_{2}$ emissions from oxygen usage are included, the total $\mathrm{CO}_{2}$ emissions from ethane oxidative dehydrogenation are $0.31 \mathrm{t} \mathrm{CO}_{2}$ per ton ethylene produced. This is $15 \%$ higher than that for ethane cracking. Ethane cracking emits less $\mathrm{CO}_{2}$ due to combustion of hydrogen although it uses more energy per ton of ethylene than ethane oxidative dehydrogenation [42]. Oxygen production requires electricity, which in primary energy terms is approximately 3-4 GJ/t oxygen [43]. The emission factor is assumed to be $60 \mathrm{~kg} \mathrm{CO}_{2} / \mathrm{GJ}$. In the future, this $\mathrm{CO}_{2}$ emission factor could be reduced by membrane processes or other efficient oxygen production processes.

Another process is propane oxidative dehydrogenation. This process produces little ethylene. Ethylene yield from steam cracking of propane is up to $45 \%$ and propylene yield is $12 \%$ [21]. Propane oxidative dehydrogenation has the potential to lead to approximately $45 \%$ savings (including primary energy use in oxygen production) on the SEC by conventional propane steam cracking, which is 15-18 GJ/t HVCs.

The rest of the technologies in Table 5 use naphtha or heavy feedstocks. SEC by catalytic cracking of naphtha is estimated to be 10-11 GJ/t HVCs. This is approximately 10-20\% less than the SEC by the state-of-the-art naphtha cracking (11-14 GJ/t HVCs). Some of these processes, developed by LG 
Table 5

Catalytic and alternative olefin technologies using conventional and heavy feedstocks

\begin{tabular}{|c|c|c|c|c|c|c|c|}
\hline & $\begin{array}{l}\text { Gas stream } \\
\text { technologies }^{\text {a }}\end{array}$ & $\begin{array}{l}\text { Ethane oxi- } \\
\text { dative de-hydro- } \\
\text { genation }^{b}\end{array}$ & $\begin{array}{l}\text { Propane oxi- } \\
\text { dative dehydro- } \\
\text { genation }^{c}\end{array}$ & $\begin{array}{l}\text { Catalytic crack- } \\
\text { ing of naphtha }\end{array}$ & $\begin{array}{l}\text { Hydro-pyrolysis } \\
\text { of naphtha }{ }^{\mathrm{e}}\end{array}$ & $\begin{array}{l}\text { Byproduct } \\
\text { upgrading }^{f}\end{array}$ & $\begin{array}{l}\text { Catalytic pyrol- } \\
\text { ysis process } \\
(\mathrm{CPP})^{\mathrm{g}}\end{array}$ \\
\hline Feed-stocks & $\begin{array}{l}\text { Ethane and } \\
\text { other gas feed- } \\
\text { stock }\end{array}$ & $\begin{array}{l}\text { Ethane and oxy- } \\
\text { gen }\end{array}$ & $\begin{array}{l}\text { Propane and } \\
\text { oxygen }\end{array}$ & Naphtha & Naphtha & $\begin{array}{l}\mathrm{C}_{4-9} \text { (from } \\
\text { steam cracking, } \\
\text { refinery, etc.) }\end{array}$ & $\begin{array}{l}\text { Crude oil, refin- } \\
\text { ery heavy oils, } \\
\text { residues, atmos- } \\
\text { pheric gas oil, } \\
\text { vacuum gas oil }\end{array}$ \\
\hline Olefins & Ethylene & Ethylene & Propylene & $\begin{array}{l}\text { Ethylene/propy- } \\
\text { lene }\end{array}$ & Ethylene & Propylene & $\begin{array}{l}\text { Ethylene/propy- } \\
\text { lene }\end{array}$ \\
\hline Reactor & $\begin{array}{l}\text { Shockwave, } \\
\text { combustion gas; } \\
\text { shift syngas; } \\
\text { plasma; etc. }\end{array}$ & $\begin{array}{l}\text { Alloy catalyst } \\
\text { reactor with } \\
\text { hydrogen co } \\
\text { feed }\end{array}$ & $\begin{array}{l}\text { Both a stem } \\
\text { reformer and an } \\
\text { (oxy-reactor); } \\
\text { or, cyclic } \\
\text { fixed-bed }\end{array}$ & Fluidized bed & $\begin{array}{l}\text { Reactors with } \\
\text { hydrogen co } \\
\text { feed but less } \\
\text { steam }\end{array}$ & $\begin{array}{l}\text { Fixed or flui- } \\
\text { dized bed }\end{array}$ & $\begin{array}{l}\text { Riser and trans- } \\
\text { fer line reactor }\end{array}$ \\
\hline Catalysts & Not applicable & $\begin{array}{l}\text { Mordenite } \\
\text { zeolite }\end{array}$ & $\begin{array}{l}\text { Zinc and cal- } \\
\text { cium aluminate } \\
\text { based }\end{array}$ & $\begin{array}{l}\text { Zeolite (or var- } \\
\text { ious metal } \\
\text { oxides) }\end{array}$ & Not applicable & Zeolite & Acidic zeolite \\
\hline$T\left({ }^{\circ} \mathrm{C}\right)$ & $625-700$ & $900-1100$ & $550-600$ & $600-650$ & $785-825$ & $580-650$ & $600-700$ \\
\hline $\begin{array}{l}\text { Total energy } \\
\text { use }^{\mathrm{h}}\end{array}$ & $\begin{array}{l}\text { Shockwave: } \\
\text { approximately } \\
\text { 8-10 GJ/t ethyl- } \\
\text { ene/HVCs }\end{array}$ & $\begin{array}{l}\text { Dow: approxi- } \\
\text { mately } 10- \\
12 \text { GJ/t ethyl- } \\
\text { ene/HVCs }\end{array}$ & $\begin{array}{l}\text { Uhde: approxi- } \\
\text { mately } \\
\text { 8-10 GJ/t } \\
\text { propylene; } \\
\text { approximately } \\
\text { 8-10 GJ/t HVCs }\end{array}$ & $\begin{array}{l}\text { KRICT: } \\
\text { approximately } \\
19 \mathrm{GJ} / \mathrm{t} \text { ethylene } \\
\text { and approxi- } \\
\text { mately } 10 \mathrm{GJ} / \mathrm{t} \\
\text { HVCs }\end{array}$ & $\begin{array}{l}\text { Blachownia: } \\
\text { approximately } \\
16-20 \mathrm{GJ} / \mathrm{t} \\
\text { ethylene and } \\
\text { approximately } \\
10-13 \mathrm{GJ} / \mathrm{t} \\
\text { HVCs }\end{array}$ & No data found & $\begin{array}{l}\text { CPP: approxi- } \\
\text { mately } 35 \mathrm{GJ} / \mathrm{t} \\
\text { ethylene and } \\
\text { approximately } \\
12 \mathrm{GJ} / \mathrm{t} \mathrm{HVCs}\end{array}$ \\
\hline Yield $(w t \%)^{\mathrm{i}}$ & $\begin{array}{l}\text { Shockwave: } \\
\text { highest ethylene } \\
\text { yield approxi- } \\
\text { mately } 90 \%\end{array}$ & $\begin{array}{l}\text { Dow: ethylene } \\
\text { yield on the } \\
\text { mass basis is } \\
\text { approximately } \\
80 \%\end{array}$ & $\begin{array}{l}\text { Uhde: propylene } \\
\text { yield on the } \\
\text { mass basis is } \\
\text { approximately } \\
84 \%\end{array}$ & $\begin{array}{l}\text { KRICT: ethyl- } \\
\text { ene } 38 \% \text {, pro- } \\
\text { pylene } 17-20 \% \text {, } \\
\text { aromatics } 30 \% \\
\text { and HVCs } 73 \%\end{array}$ & $\begin{array}{l}\text { Blachownia: } \\
\text { Ethylene yield } \\
36-40 \% \text { and } \\
\text { HVCs yield } \\
70 \%\end{array}$ & $\begin{array}{l}\text { UOP: propylene } \\
\text { yield from } \\
\text { steam cracking } \\
\text { is } 30 \% \text { and } \\
\text { HVCs yield } \\
85 \%\end{array}$ & $\begin{array}{l}\text { CPP: ethylene } \\
21 \%, \text { propylene } \\
18 \%, \mathrm{C}_{4} 11 \%, \\
\text { aromatics } 15 \% \\
\text { and HVCs yield } \\
60 \%\end{array}$ \\
\hline Status & $\mathrm{Lab}$ & $\mathrm{Lab}$ & Commercial & Pilot plant & Commercial & Commercial & $\mathrm{Lab}$ \\
\hline
\end{tabular}

A steam cracker has a large, tubular fired furnace; feedstock is indirectly heated; no catalysts use in pyrolysis; temperature $750-1100{ }^{\circ} \mathrm{C}$; no hydrogen or oxygen need. Process energy for the average naphtha cracking technology is approximately $9 \mathrm{GJ} / \mathrm{t}$ naphtha.

${ }^{a}$ Gas stream data come from [39]. Shockwave data come from [40]. Combustion gas could save 0.3 GJ/t ethylene [70].

b Per pass ethylene yield on mol basis is typically approximately 30\%. Data is based on [71,72]. Oxygen production needs 3-4 GJ/t oxygen and this is accounted for. 
${ }^{c}$ Per-pass propylene yield on the mol basis is typically approximately 30-40\%. Data is based on [62,63]. Oxygen production needs 3-4 GJ/t oxygen and this is accounted for. Propane steam cracking has a SEC of 20-25 GJ/t ethylene and 15-18 GJ/t HVCs with the yields of ethylene $42 \%$ and propylene $11 \%$ [21]. Other similar processes include Oleflex by UOP, Catofin by ABB Lummus, etc.

${ }^{\mathrm{d}}$ KRICT data is based on [48]. Also, LG claims ethylene up by $20 \%$ yield and propylene yield up by 10 and $10 \%$ energy savings on the current SECs of naphtha cracking in Korea [52,73]. The SEC $7.5 \mathrm{GJ} / \mathrm{t}$ naphtha is assumed based on [74]. Other processes are: AIST ethylene/propylene yield together 60-70 and $20 \%$ energy savings per ton of ethylene and propylene is claimed [74,75]. VNIIOS ethylene yields 30-34\% and propylene yields 18-20\% [76]; Asahi ethylene $22 \%$, propylene $20-40 \%$ [25].

e Hydro-pyrolysis was used in Blachownia Chemical Works in Poland, which claims a $20 \%$ increase of the average ethylene yield and approximately $30 \%$ less energy use [77]. The technology is not offered by major licensors.

${ }^{\mathrm{f}}$ Olefins upgrading data is based on [44,60]. A similar industrial process is Metathesis [78]. Metathesis is an olefin conversion process, which in this case converts ethylene and butane-2 to propylene [12]. It is basically an extension of naphtha cracking to increase the yield of propylene.

g CPP data comes from [45,46,79]. The SEC $7.5 \mathrm{GJ} / \mathrm{t}$ feedstock is estimated. A review of several similar processes can be found in [49].

h Typically, current ethane cracking has an average SEC 17-21 GJ/t ethylene and 16-19 GJ/t HVCs. Naphtha cracking has a SEC 26-31 GJ/t ethylene and

14-17 GJ/t HVCs. The state-of-the-art naphtha cracking has 20-25 GJ/t ethylene and 11-14 GJ/t HVCs.

i Typically, ethane cracking has $81 \%$ ethylene yield. Naphtha cracking has $30 \%$ ethylene and $15 \%$ propylene yield. 
(a major Korean chemical company) and AIST (a Japanese research institute), are claimed to have the potential to be commercialized soon.

Hydro-pyrolysis could save approximately 9\% less (including primary energy use in hydrogenmethane fraction) than the SEC by state-of-the-art naphtha cracking. Several factors enable these energy savings: higher yields, lower temperature in the furnace, low coking and lower steam requirement. It is a non-catalytic process.

Byproduct upgrading technologies produce olefins by processing the by-products (ranging from $\mathrm{C}_{4}$ to $\mathrm{C}_{9}$ ) from conventional steam cracking or from a refinery [44]. As an add-on process to naphtha cracking, byproduct upgrading technologies can raise the total propylene yield of naphtha cracking from an average $15-30 \%$. This process has a potential saving of approximately $7-10 \%$ compared to the SEC by state-of-the-art naphtha cracking.

Using heavy feedstocks, such as crude oil, the catalytic pyrolysis process $(C P P)$ saves approximately $12 \%$ on the SEC of state-of-the-art naphtha cracking. Because CPP feedstock can be crude oil and other heavy feedstock, energy use in naphtha production is avoided, which is approximately 2-3 GJ/t naphtha [34] If this is taken into account in the comparison with naphtha cracking, the energy savings by CPP would be approximately $20 \%$. Another important reason for energy saving is the mild reaction conditions in CPP. Its reaction temperatures are around $650-750{ }^{\circ} \mathrm{C}$, which is $150-350{ }^{\circ} \mathrm{C}$ lower than steam cracking $[45,46]$.

The energy savings estimated here are due to improvement of energy efficiency in the pyrolysis section. If advanced separation technologies (mentioned under 6.2) are also applied, then the energy savings by catalytic olefin technologies on the SEC by state-of-the-art naphtha cracking could be up to approximately $40 \%$. Among the alternative olefin technologies discussed, gas stream and hydropyrolysis have not been actively pursued by the industry in recent years. However, catalytic olefin technologies are under intensive R\&D, especially in China and Japan.

\subsection{Reactors and catalysts}

It is interesting to discuss further possibilities for energy saving by the catalytic olefin technologies just mentioned. ${ }^{12}$ The emergence of catalytic olefin technologies is in line with the recent discussion on energy-saving through process intensification. ${ }^{13}$ Catalytic olefin technologies basically can be divided into two categories: acidic catalytic cracking and thermal catalytic pyrolysis [48]. Acidic cracking is associated with zeolite catalysts, FCC-like riser/bed reactors and heavy feedstocks. Thermal catalytic pyrolysis is associated with various kinds of metal oxide catalysts and naphtha. The reactors are often similar to tubular furnaces used in steam cracking, but FCC-like reactors are also being tested. The reactors and catalysts used in these new technologies (in Table 5) share features with conventional refinery FCC reactors, which are fixed or fluidized bed catalytic cracking reactors. China's SINOPEC has named its catalytic olefin technologies 'FCC family techniques' [49]. FCC reactors are smaller than pyrolysis furnaces. Also, moving beds and catalysts used in FCC enable intensive contact between catalysts, reactors and feedstocks (by maximizing contact surface) and consequently, such intensity leads to efficient heat transfer.

\footnotetext{
${ }^{12}$ This is not to say all catalytic pyrolysis technologies for olefin production save energy in comparison with state-of-the-art steam cracking. Our discussion is limited to those listed in Table 5 that are believed to have energy saving potentials.

${ }^{13}$ This term basically means that better heat and mass transfer in smaller and faster reaction systems with less steps lead to higher conversion, better efficiency, less waste and safer control systems [47].
} 


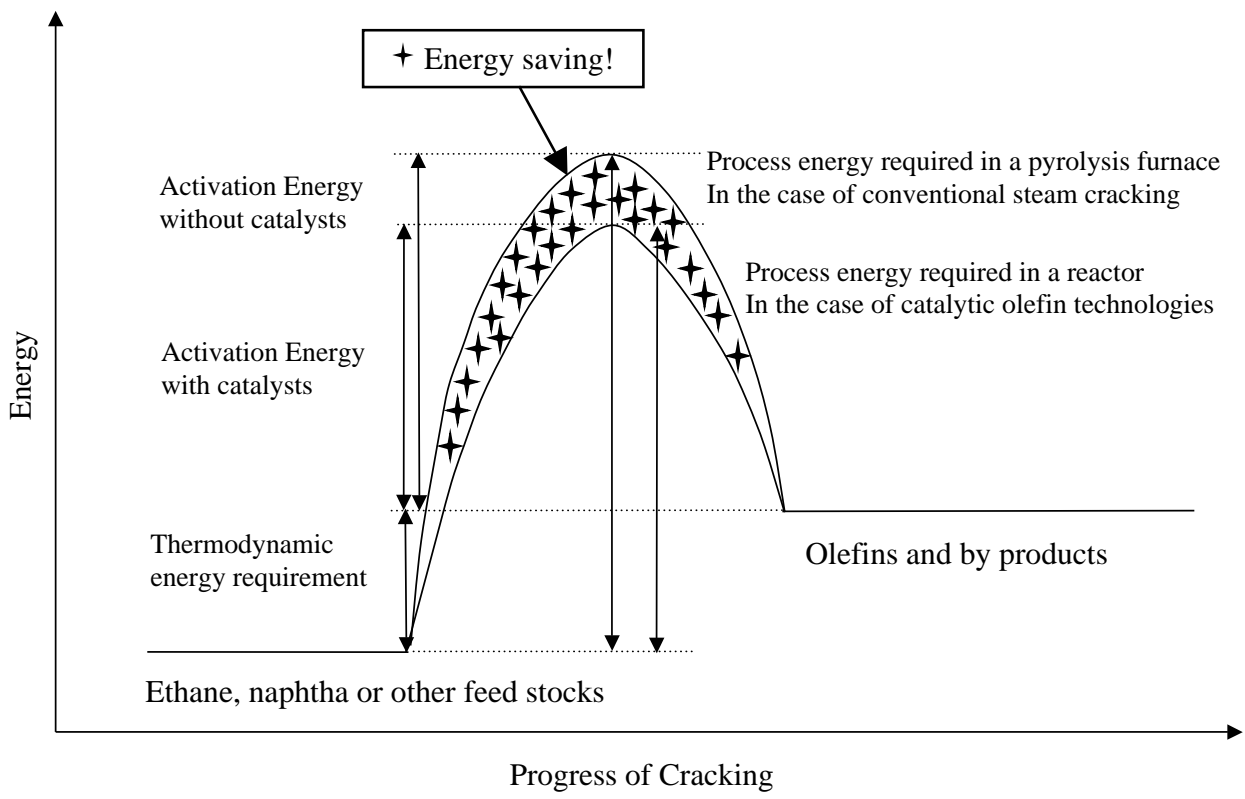

Fig. 4. Simplified energy profile of conventional steam cracking and catalytic olefin technologies.

Unsurprisingly, FCC reactors ${ }^{14}$ are known for using less energy in terms of SEC/t feedstock (SEC approximately 2-3 GJ/t feedstock) than steam cracking furnaces (SEC approximately 5-9 GJ/t ethane or naphtha). Because catalytic reactors usually operate at lower temperatures than steam cracking, it is possible to use recovered waste heat as a source of process energy besides fuel combustion.

The use of catalysts is known for saving energy. Zeolite FCC catalysts adopted by US refineries in 1977 have helped to save 200 million barrels of crude oil, or 30 million tons in the US alone [51]. Similarly, many of the catalytic technologies mentioned in Table 5 use zeolite catalysts or use metal oxides. ${ }^{15}$ Fig. 4 illustrates that catalytic olefin technologies can save activation energy use in conventional steam cracking. There are three reasons for such energy saving.

- First, these catalysts provide an alternative route to steam cracking with the use of lower activation energy for $\mathrm{C}-\mathrm{C}$ bonds rupture. In the case of $\mathrm{CPP}$, this means the cracking can be carried out at moderate temperature and pressure in comparison with steam cracking. Also, most of the catalysts cannot withstand extremely high temperatures and pressures as in steam cracking (up to $1100{ }^{\circ} \mathrm{C}$ and 700 bar). Consequently, the temperatures for the new catalytic naphtha cracking processes are $150-250{ }^{\circ} \mathrm{C}$ lower than those for steam crackers (Table 5).

\footnotetext{
${ }^{14} \mathrm{FCC}$ reactors operate at low temperature: approximately $450-600{ }^{\circ} \mathrm{C}$, which is $200-400{ }^{\circ} \mathrm{C}$ less than steam cracking [50]. However, it is commonly known that FCC ethylene yield usually only is $1-2 \%$ and propylene yield is $5 \%$ while naphtha yield is over $50 \%$ and cycle oil yield is $20 \%$ [34].

${ }^{15}$ Zeolite catalysts are complex alumino-silicates, large lattices of aluminum, silicon and oxygen atoms. In the case of FCC, zeolite catalysts lead to formation of carbonium ions. These ions then reorganize and lead to various FCC products. In the case of catalytic olefin technologies, the combined use of zeolite and other catalysts lead to formation of both carbonium-ions and free-radicals. They are then reorganized and eventually lead to light olefins, aromatics and other products.
} 
- Second, catalysts improve selectivity to desired products, such as propylene. Even if the same operating conditions as those of steam cracking are applied for catalytic cracking, the total olefin yield by LG's catalytic pyrolysis technology is still enhanced by at least $15 \%$ [52].

- Third, coke formed during the cracking process is constantly removed by catalysts that are in turn decoked through catalyst regeneration or catalyst decoking. As said earlier, coke lowers energy efficiency by hindering heat transfer.

Earlier attempts to catalytically convert heavy hydrocarbons to light olefins often showed that the use of catalysts is often problematic because of thermodynamic equilibrium limitations, coking, low yields of olefins and high yield of low-value by-products ${ }^{16}[49,53]$. The new catalytic technologies in Table 5 have made some progress in solving these problems, but more improvement is still needed.

- Regarding the equilibrium limitation, oxygen is used to drive the reaction towards the desired direction and to take advantage of heat generated by oxidation. As a result, excessive heating and high pressure are not required and thereby energy efficiency is improved [50]. At the same time, oxygen can also burn off coke on the catalysts. Also, reactors using inorganic catalytic membranes could separate oxygen, ethane/naphtha, hydrogen and other products to reduce undesired reactions and improve the conversion in the equilibrium limited reaction.

- Older metal oxide catalysts were prone to coking and quickly deactivate. Therefore, high temperatures and short residence time were required to reduce coking. High temperatures $\left(800{ }^{\circ} \mathrm{C}\right.$ or above) and extremely short residence time (in milliseconds), however, are often very harsh on catalysts and result in quick deactivation of catalysts and a short lifetime. Recently, new zeolite catalysts, such as metal, silica and hybrid, have shown to cause less coking and to be more effective under higher temperatures $[46,54]$. One recent patent on catalytic olefin technologies claims that new catalysts can reduce $\mathrm{CO}_{2}$ and methane contents in the air stream from catalyst regeneration by 90 and $50 \%$, respectively, in comparison to the air stream from steam cracking [50].

- Older catalysts often show strong selectivity to aromatics and heavy hydrocarbons instead of light olefins. New catalysts, such as Ga-P zeolite, suppress aromatization and provide relatively high yield of ethylene and propylene.

\subsection{Short- and long-term prospects}

According to major worldwide licensors and research institutions, we contacted between 2002 and 2004, currently none of these catalytic olefin technologies listed in Table 5 are fully mature and economically competitive in comparison with state-of-the-art steam cracking technologies. Nevertheless, it is of interest to discuss the short and long-term prospects of catalytic olefin technologies.

In the short term, catalytic olefin technologies appear to be driven by two economic factors: strong demand for propylene and low cost feedstock.

\footnotetext{
${ }^{16}$ Coke can be significant even at high reaction temperatures. It can currently only be burned through catalyst regeneration and is very problematic if it remains in the final products. Catalytic olefin technologies often yield large amount of methane and hydrogen, which need much energy at cryogenic conditions for separation. Other low-value by-products, such as aromatic-rich gasoline is difficult to use due to instability caused by olefins and additional processing will lead to high costs.
} 
- Propylene demand is an important economic factor. The three catalytic technologies in the middle of Table 5 are sometimes referred to as 'propylene on purpose' [10]. For the same reason, conventional FCC used in refineries also became attractive for R\&D since it yields considerable amount of propylene (up to $17 \mathrm{wt} \%$ ) and is likely to supplement propylene supply unfulfilled by steam cracking.

- Heavy feedstocks that are heavier than naphtha, such as gas oil and heavy residues indicated in the center of Table 5, are cheaper than naphtha and ethane and they can also yield multiple high value byproducts. Such feedstocks attract much attention in the US, Europe and Asia. Cracking heavy feedstock can enhance competitiveness compared to ethane cracking in the Middle East. Therefore, the overall economics for upgrading heavy feedstock to high value olefin products, especially propylene, look quite attractive. Besides unresolved technical problems, the question whether the production volume can be increased further by using these new technologies will be answered by propylene market pull and by competition between the costs of conventional and of heavy feedstocks.

In the long term, more $\mathrm{R} \& \mathrm{D}$ on catalytic olefin technologies can be expected because of their potentials for energy savings as well as for upgrading low-value heavy feedstocks. Catalysis has brought tremendous progresses to many fields in the chemical industry, but unfortunately it has not been capitalized on light olefin production. Steam cracking is essentially a non-catalytic and non-selective process. Catalysts have never been widely used in the pyrolysis section in steam cracking to optimize energy efficiency. The application of catalysts in cracking naphtha and ethane has only become attractive since the beginning of 1990s. Besides, those institutions in Korea, Japan and China (mentioned in Table 5), major licensors (e.g. Stone and Webster and ABB Lummus) and olefin producers (e.g. ExxonMobil and BP) are also filing patents on catalytic olefin technologies. Recently, catalytic processes developed by AIST, Sinopec/Stone and Webster and VNIIOS are said to be under commercial tests [48]. Adoption of FCC-like catalytic olefin technologies has been expected for more than 10 years. Whether these new processes can replace steam cracking will depend on how well they mature both technically and economically in the next 20-30 years.

In a word, there is a rising interest in applying special reactors and catalysts to control yield and thereby improve energy efficiency, but the future development of catalytic olefin technologies will be strongly affected by the maturity of catalytic technologies, market pull and feedstock cost competition.

\section{Conclusion}

Issues concerning the reduction of energy use, costs and emissions by olefins production initiated this analysis of olefin technologies. The results of energy analysis indicate the most energy-consuming sections, e.g. the pyrolysis section accounting for approximately $65 \%$ of total energy use and approximately $75 \%$ of the total exergy losses. An overview of state-of-the-art naphtha cracking technologies offered by licensors shows that approximately $20 \%$ savings on the current average energy use are possible. Advanced naphtha cracking technologies in the pyrolysis section, such as advanced coil and furnace materials, could together lead to up to approximately $20 \%$ savings on the energy use by state-of-the-art technologies. Improvements in the compression and separation sections could together lead to up to approximately $15 \%$ savings on the energy use by state-of-the-art technologies. Alternative olefin technologies apply special reactors, catalysts or additional materials such as oxygen and hydrogen to crack conventional and heavy feedstocks. In particular, catalytic olefin technologies can lead to higher 
yields of valuable chemicals such as propylene at lower reaction temperatures. Due to energy efficiency improvement in the pyrolysis section, catalytic naphtha cracking could possibly save up to approximately $20 \%$ compared to the energy use by the state-of-the-art naphtha cracking.

\section{Acknowledgements}

This $\mathrm{PhD}$ project is financed by Energy Research Foundation of the Netherlands (ECN) and Utrecht Energy Research Center (UCE). Also, special thanks to C. Bowen at Stone \& Webster, H. Chang at the Tamkang University in Taiwan, J. Hugill at ECN, A. Laghate at Technip-Coflexip, P. Pujado at UOP LLC and J. Siddall at Dow Chemicals.

\section{References}

[1] IEA. Energy statistics of OECD countries 2001/2002 and energy statistics of non-OECD countries 2001/2002 (2004 Edition). Paris: International Energy Agency; 2004.

[2] DOE. Manufacturing Consumption Energy Survey. Washington DC: Energy Information Administration of the US Department of Energy. See also at www.eia.doe.gov/emeu/mecs/iab98/chemicals/index.html; 1998.

[3] Nakamura D. Special report: ethylene capacity rising, margins continue to suffer. Oil Gas J 2002.

[4] IPCC. The third assessment report: climate change -mitigation. Geneva, Switzerland: Intergovernmental Panel on Climate Change (IPCC); 2001.

[5] Albright LF, Crynes BL, Nowak S. Novel production methods for ethylene, light hydrocarbons and aromatics. New York: Marcel Dekker; 1992.

[6] Stratton A, Hemming DF, Teper M. Ethylene production from oil, gas and coal-derived feedstock. London: Coal Research at International Energy Agency (IEA); 1983.

[7] Worrell E, Beer JD, Faaij A, Blok K. Potential energy savings in the production route for plastics. Energy Conserv Manage 1994;12(35):1073-85.

[8] Ren T, Patel M, Blok K. Steam cracking and natural gas-to-olefins: a comparison of energy use and economics. 2005 spring national meeting of American chemical engineering association (AIChE). Atlanta, New York: American Institute of Chemical Engineers; 2005.

[9] EC-BREF. Integrated pollution prevention and control (IPPC) reference document on best available techniques in the large volume organic chemical industry February 2002. Lower olefins process BREF, Seville, Institute for Prospective Technological Studies (Technologies for sustainable development) European IPPC Bureau; 2002.

[10] Thoelke M. CMAI global outlook: ethylene, propylene and butadiene. The fifth EMEA petrochemical technology conference, June 23-26, Paris. London: Euro Petroleum Consultancy Ltd; 2003.

[11] EIA. International natural gas information. Washington, DC: Energy Information Administration at the US Department of Energy. See also at www.eia.doe.gov.; 2003.

[12] Weissermel K, Arpe H. Industrial organic chemistry. 4th ed. Weinheim: Wiley; 2003.

[13] Bailey K. Optimize heat exchanger operations by minimizing fouling. Hydrocarbon Process 1999.

[14] Perry R, Green D. Perry's chemical engineers' handbook. 6th ed. Columbus, OH: McGraw-Hill; 1987.

[15] Szargut J, Morris DR, Steward FR. Exergy analysis of thermal, chemical and metallurgical processes. New York: Hemisphere; 1988.

[16] Yabe A, Ohmori T, Okuma K, Nonoichi Y, Hijikata K. Energy and exergy analysis of high temperature naphtha cracking process in an ethylene center. International symposium on advanced energy conversion system and related technologies, Nagoya, Japan. Nogoya, Japan: The Japanese Society of Chemical Engineers; 1995 (First author's address: Mechanical Engineering Laboratory, AIST, MITI, 1-2 Namiki, Tsuku ba Science City, Ibaraki 305, Japan). 
[17] Chang H. Exergy analysis and exergoeconomic analysis of an ethylene process. Tamkang J Sci Eng 2001;2(4):95-104 (published by the Department of Chemical Engineering at the Tamkang University, 151 Ying Chuan Road, Tamsui, Taipei Hsien, Taiwan 25137, Republic of China). See also at www2.tku.edu.tw/ tkjse/4-2/4-2-3.pdf.

[18] Solomon. Worldwide olefins plant performance analysis 1995, quoted in 'Energy efficiency improvement in ethylene and other petrochemical production' by D. Phylipsen, et al., report NW\&S 99085 (1999), Department of Science, Technology and Society at Utrecht University, Utrecht in the Netherlands. Windsor: Solomon Associates Ltd; 1995.

[19] Energetics, energy and environmental profile of the US chemical industry, Columbia, Maryland. Study prepared by Energetics Co. for the Office of Industrial Technology at the US Department of Energy; 2000.

[20] Brown HL. Energy analysis of 108 industrial processes. Washington, DC: US Department of Energy; 1985.

[21] Matthews R. Personal communications with Dr Martin Patel from the STS department at the Utrecht University in the first half of 2002. London: Guthrie-Matthews Consulting Limited; 2002.

[22] Hydrocarbon-processing. Petrochemical processes 2003; March 2003. See also www.hydrocarbonprocessing.com

[23] Buffenoir MH. Mega crackers mean mega challenges by technip-coflexip. The fifth EMEA petrochemical technology conference on June 23-26, Paris. London: Euro Petroleum Consultancy Ltd; 2003.

[24] KBR. Changing world of global ethylene business. 2000 Global super project conference, Dubai, Saudi Arabia. Norcross, GA: World Development Federation; 2000.

[25] Picciotti M. Novel ethylene technologies developing, but steam cracking remains king. Oil Gas J 1997.

[26] Nieuwlaar E. Personal communications with experts in the olefin industry quoted in 'Sector Study for the Chemical Industry' (Report Nr. NWS-E-2001-19). Utrecht, The Netherlands: Utrecht University; 2001.

[27] DOE. Membrane separation recovers olefins (Chemicals project fact sheets). Washington, DC: Office of Industrial Technologies at US Department of Energy; 2003. See also: www.oit.doe.gov/chemicals/factsheets.

[28] Kolmetz K. Advances in cracking furnace technologies. Refinery technology conference on 12-14 December, Dubai, Saudi Arabia. London: European Refinery Technology Conference (ETRC); 2002.

[29] DOE. Fabrication and testing of a prototype ceramic furnace coil for chemical and petrochemical processing. Washington, DC: Office of Industrial Technology at the US Department of Energy; 2003. See also: www.oit.doe.gov/chemicals/ factsheets.

[30] Albano J, Olszewski E, Fukushima T. Gas turbine integration reduces ethylene plant's energy needs. Oil Gas J 1992.

[31] IDEE. Industriele Databank voor Energie Efficiency, Versie 7. Utrecht, The Netherlands: NOVEM of the Dutch Ministry of Economic Affairs; 2000 [in Dutch].

[32] Heida B, Bohner G, Kindler K. Consider divided-wall technology for butadiene extraction. Hydrocarbon Process 2002.

[33] Vaartjes J. Integrated distillation column. Energietechniek 2002;10:24 [in Dutch].

[34] Hydrocarbon-processing. Refining processes 2002; November 2002. See also www.hydrocarbonprocessing.com

[35] Staudt-Bickel C, Koros W. Olefin/paraffin gas separations with 6 FDA-based ployimide membranes. J Memb Sci 2000; 170:205-14.

[36] Bernadardo P, Criscuoli A. Application of membrane unit operations in ethylene process. Clean Technol Environ Policy 2004;6:78-95.

[37] Smit R, Beer J, Worrel E, Blok K. Styrene: long term industry energy efficiency importance. Technology description. Report Nr. 94076, Utrecht, The Netherlands. The Netherlands: Dep. of Science, Technology and Society at Utrecht University; 1994.

[38] Ameringer GE. The gas/ethylene plant: concept and integration. Gas Technol 2000;2(5):119.

[39] Pujado P, Greer D, Andersen J, Foley T, Bhirud V. The role of new technology in the light olefins industry. 2002 spring national meeting of the American Institute of Chemical Engineers (AIChE). Houston, NY: American Institute of Chemical Engineers; 2002.

[40] Knowlen E. Petrochemical pyrolysis with shock waves (AIAA Paper 95-0402). Reston, VA: American Institute of Aeronautics and Astronautics; 1995.

[41] Mattick T. Personal communications on shockwave technology in January of 2003. Seattle, WA: University of Washington; 2003.

[42] Siddall J. Catalytic autothermal partial oxidation (internal report). Houston: Dow Chemical; 2000.

[43] IKARUS. Personal communication with Linde AG. Quoted in IKARUS (Instrument for climate changing gas reduction strategies), Frankfurt, FhG-ISI, GEU, FfE and Oko Institute; 1994 [in German]. 
[44] Gregor J. Meeting the changing needs of the olefins market by UOP LLC. The fifth EMEA petrochemical technology conference on June 23-26, Paris. London: Euro Petroleum Consultancy Ltd; 2003.

[45] Xie C, Wang X. Commercial trial of catalytic pyrolysis process for manufacturing ethylene and propylene. The 17th world petroleum congress on Sept 1-5, Rio de Janeiro, Brazil. London: World Petroleum Council; 2002.

[46] USPTO. Process for production of ethylene and propylene by catalytic pyrolysis of heavy hydrocarbons (US Patent 6,210,562). US Patent Office: China Petrochemical Corporation and RIPP; 2001.

[47] Dautzenberg FM, Mukherjee M. Process intensification using multifunctional reactors. Chem Eng Sci 2001;56:251.

[48] Han SS, Kim JN, Lee CW, Park YK. Catalytic cracking of heavy naphtha and olefin separation in atmospheric temperature. Seoul, Korea: Advanced Chemical Technology Division, KRICT Co.; 2002. See also: www.krict.re.kr.

[49] Deng R, Wei F, Jin Y, Zhang Q, Jin Y. Downer catalytic pyrolysis (DCP): a novel process for light olefins production. Chem Eng Technol 2002;(25):711-6.

[50] USPTO. Hybrid catalyst for deep catalytic cracking of petroleum naphthas and other hydrocarbon feedstocks (US Patent application 20,040,014,593). US Patent Office: Concordia University; 2004.

[51] UYSEG. FCC cracking saves energy. York, UK: The University York Science Education Group; 2004. See also: http:// www.uyseg.org/catalysis/pages/cat_frames.htm.

[52] Jeong SM, Chae JH. Catalytic pyrolysis of naphtha on the KVO3 based catalyst. Catal Today 2002;257-64.

[53] Laszlo L. Oxidative conversion of lower alkanes to olefins. PhD Thesis. F.v.V. (supervisor), Twente, The Netherlands, University of Twente; 2002.

[54] USPTO. Production of naphtha and light olefins (US patent application number 20,020,063,082). US Patent Office: Exxon Mobil, Inc.; 2002.

[55] Jennings C. Adding value through growth and innovation: NAFTA region olefins complex, Houston. Houston: BASF; 2001.

[56] Wells GM. Handbook of petrochemicals and processes. Hampshire, UK: Gower Publishing Company; 1991.

[57] Gielen DJ, Groenendaal BJ. The future of the petrochemical industry (report nr. ECN-C-99-052). Petten, The Netherlands: Energy Research Center of the Netherlands (ECN Energieonderzoek Centrum Nederland); 1999.

[58] Steinberg M, Fallon PL, Sundaram MS. The flash pyrolysis and methanolysis of biomass for production of ethylene, benzene and methanol. New York: Marcel Dekker; 1992.

[59] ABB-Lummus. Metathesis: refinery and ethylene plant applications. ARTC petrochemical conference on February 12-14, Kuala Lumpur, Malaysia. Houston: Aspen Tech; 2001.

[60] Tallman M. KBR's superflex process to upgrade F-T liquids at Sasol. Fifth EMEA petrochemical technology conference on June 23-26, Paris. London: Euro Petroleum Consultancy Ltd; 2003.

[61] Bolt HV. Linde propylur process integrated into a steam cracker. Fifth EMEA petrochemical technology conference in June 23-26, Paris. London: Euro Petroleum Consultancy Ltd; 2003.

[62] Sud-Chemie. Catofin propane dehydrogenation for propylene. Munich, Germany: Sud-Chemie; 2003. See also: http:// www.sud-chemieinc.com/houdry_propane.shtml.

[63] Uhde. The Uhde Star process: oxydehydrogenation of light paraffins to olefins. Dortmund, Germany: Uhde GmbH; 2003. See also: www.uhde.biz/cgi-bin/download.cgi/pdf/broschueren/Oil_Gas_Refinery/The_Uhde_STAR_Process.pdf.

[64] Spletter KG, Ruwe WP. Gulf coast ethylene margins begin in this issue. Oil Gas J 2002;16:46-9.

[65] WEC. Energy efficiency improvement utilizing high technology. An assessment of energy use in industry and buildings, report and case studies. London: World Energy Council; 1995.

[66] DOE. Ethylene process design optimization. Washington, DC: US Department of Energy; 2001. See also: www.oit.doe. gov/chemicals/factsheets.

[67] Neelis M, Patel M, Feber MD. Improvement of $\mathrm{CO} 2$ emission estimation from the non-energy use of fossil fuels in the Netherlands (report nr. NW and S E-2003-10 prepared for NOVEM and VROM). Utrecht, The Netherlands: Utrecht University; 2003.

[68] Kaiser V, Cintio D, Picciotti R. Ethylene plant energy analysis. In: 1993 spring national meeting of American Institute of Chemical Engineers. Houston, NY: American Institute of Chemical Engineers; 1993. p. 1993.

[69] Chang H. Personal communication on exergy analysis of separation processes in steam cracking in the April of 2003. Dep. of Chemical Engineering at the Tamkang University in Taipei Taiwan; 2003. 
[70] IDEE. Kraakscherpteregeling voor betere selectiviteitsbeheering in etheenfabriek. Utrecht, The Netherlands: NOVEM of the Dutch Ministry of Economic Affairs; 2000 [in Dutch].

[71] USPTO. Catalytic oxidative dehydrogenation process (US patent 6,452,061). US Patent Office: Regents of the US of Minnesota (Minneapolis); 2003.

[72] Huff M, Schmidt LD. Ethylene formation by oxidative dehydrogenation of ethane over monoliths at very short contact times. J Phys Chem 1993;111822-50.

[73] ChemicalWeek. LG develops catalytic naphtha cracking process.: Chemical Week; 2002.

[74] Yoshimura Y, Murata K, Mizukami F. Catalytic cracking of naphtha to light olefins. Catal Surv Jpn 2001;2(4):157-69 (see also at http://www.kluweronline.com).

[75] SRI. Abstract of process economics program report 248: steam cracking for olefins production (July-2003). Menlo Park, CA: SRI International Consulting Co; 2003.

[76] VNIIOS. Catalytic pyrolysis of petroleum fractions to produce ethylene and propylene. Moscow: VNIIOS; 2003. See also: http://www.vniios.ru/english/index.htm\#0.

[77] Taniewski M. Personal communication in May of 2003 and February of 2004. Gliwice: Silesian Technical University in Poland; 2004.

[78] Stanley SJ, Kukandar K. Improving ethylene plant economics with metathesis. The 15th ethylene producer conference. New Orleans, NY: American Institute of Chemical Engineers; 2001.

[79] Bowen C, Reid JA. Emerging olefins technology. 2002 spring national meeting of American Institute of Chemical Engineers (AIChE). New Orleans, NY: American Institute of Chemical Engineers; 2002. 